\title{
Precision Approaches in the Management of Colorectal Cancer: Current Evidence and Latest Advancements towards Individualizing the Treatment
}

\author{
Rebecca A. Shuford ${ }^{1}$, Ashley L. Cairns ${ }^{1}$ and Omeed Moaven ${ }^{2, *(1)}$ \\ 1 Department of Surgery, Wake Forest University, Winston-Salem, NC 27157, USA; \\ rshuford@wakehealth.edu (R.A.S.); acairns@wakehealth.edu (A.L.C.) \\ 2 Section of Surgical Oncology, Department of Surgery, Mayo Clinic Florida, Jacksonville, FL 32224, USA \\ * Correspondence: moaven.omeed@mayo.edu; Tel.:+1-904-953-2214
}

Received: 30 September 2020; Accepted: 17 November 2020; Published: 23 November 2020

Simple Summary: Metastatic colorectal cancer (mCRC) represents a significant burden in cancer-related morbidity and mortality. The study of mCRC-related genetic alterations and the molecular landscape of the disease has been ongoing and continues to improve the efficacy of the available treatment options. Here, we review various molecular pathways that are involved in colorectal carcinogenesis with driving mutations that could be targeted for precision approaches in the treatment of $\mathrm{mCRC}$. We summarize groundbreaking clinical trials that are shaping the evolving role of precision approaches in the practice guidelines and discuss the latest advancements in emerging new modalities, novel technologies, and future directions toward individualizing the managemet approaches to the treatment of colorectal cancer.

\begin{abstract}
The genetic and molecular underpinnings of metastatic colorectal cancer have been studied for decades, and the applicability of these findings in clinical decision making continues to evolve. Advancements in translating molecular studies have provided a basis for tailoring chemotherapeutic regimens in metastatic colorectal cancer (mCRC) treatment, which have informed multiple practice guidelines. Various genetic and molecular pathways have been identified as clinically significant in the pathogenesis of metastatic colorectal cancer. These include rat sarcoma (RAS), epithelial growth factor receptor (EGFR), vascular endothelial growth factor VEGF, microsatellite instability, mismatch repair, and v-raf murine sarcoma viral oncogene homolog $b 1$ (BRAF) with established clinical implications. $R A S$ mutations and deficiencies in the mismatch repair pathway guide decisions regarding the administration of anti-EGFR-based therapies and immunotherapy, respectively. Furthermore, there are several emerging pathways and therapeutic modalities that have not entered mainstream use in $\mathrm{mCRC}$ treatment and are ripe for further investigation. The well-established data in the arena of targeted therapies provide evidence-based support for the use or avoidance of various therapeutic regimens in mCRC treatment, while the emerging pathways and platforms offer a glimpse into the future of transforming a precision approach into a personalized treatment.
\end{abstract}

Keywords: molecular targeted therapies; colorectal cancer; precision oncology; therapy resistance

\section{Introduction}

Colorectal cancer (CRC) is the third most common malignancy and the fourth leading cause of cancer-related death worldwide [1]. Its incidence has been increasing in recent years as modern lifestyle changes known to increase CRC risk (including dietary changes, obesity, sedentary behaviors, and alcohol and tobacco use) become more widespread, and CRC screening has been widely adopted [2]. 
These social and epidemiological changes, coupled with improvements in preventive care, sanitation, and communicable disease prevention, have led to an increased age expectancy and an older population with a higher risk of developing CRC. Although adults aged 65 and older are between three and 30 times as likely to be diagnosed with CRC in comparison to younger adults, there is also a trend towards increasingly early onset of CRC in younger individuals [2,3]. Multiple guidelines for the screening, treatment and surveillance of CRC exist. While colonoscopy is the gold standard for screening and diagnosis of CRC, alternatives such as fecal occult blood testing and fecal immunohistochemical testing are also utilized. The United States Preventive Services Task Force (USPSTF) recommends screening asymptomatic adults aged 50 years and older for CRC and the National Comprehensive Cancer Network routinely publishes and updates guidelines for treatment and surveillance of CRC, which are widely used in clinical practice [4,5]. Unfortunately, many barriers prevent patients from receiving appropriate CRC screening. Patient anxiety, out of pocket cost of the procedure, lack of insurance coverage, negative prior clinical experiences have all been linked to under-screening or lack of screening for CRC [6-8].

As the number of patients impacted by CRC has climbed, basic/translational research efforts have improved our understanding of the underlying pathophysiology of the disease. The adenoma-carcinoma sequence is a classic model detailing the progressive accumulation of genetic mutations leading from the transition of normal colonic or rectal tissue to an adenomatous polyp, with subsequent inactivation of tumor suppression genes (i.e., Adenomatous polyposis coli (APC), Tumor protein 53 (TP53)), activation of oncogenes (i.e., rat sarcoma $(R A S)$ ) and eventual development of CRC [1,9]. However, with further advancements, this model has been challenged by the introduction of discrete mechanisms of CRC pathogenesis (which account for approximately 15\% cases of sporadic CRC) [9]. For instance, v-raf murine sarcoma viral oncogene homolog b1 (BRAF) mutations and microsatellite instability (MSI) have been implicated in the serrated pathway, in which serrated polyps develop activation of distinct oncogenes [10]. With advancements in our understanding of genetic alterations in CRC, the role of precision medicine is becoming more essential. Only $10 \%$ or less of patients have CRC secondary to hereditary syndromes such as familial adenomatous polyposis (FAP) or hereditary nonpolyposis colorectal cancer (HNPCC), which have associations primarily with CRC in addition to other malignancies as well [1,11]. These hereditary CRC syndromes are associated with specific genes, including MutL homolog 1 (MLH1), MutS homolog 2 (MSH2), APC, and mutY DNA glycosylase $(M U T Y H)$ [1]. The breadth of genetic involvement in CRC provides an opportunity to expand the evaluation and treatment linked by involved genes, in an era of individualized or precision medicine.

Advancements in translating molecular studies have led to a growing role for personalized treatment for individual patients based on their specific disease process rather than a "one-size-fits-all" approach [12]. Examples of such clinical applications include the use of anti- vascular endothelial growth factor (VEGF) monoclonal antibodies (mAb) (i.e., bevacizumab) in metastatic CRC (mCRC) or anti-epidermal growth factor receptor (EGFR) $\mathrm{mAb}$ (i.e., cetuximab) in panRAS and BRAF wild type (wt) CRC [13]. Multiple guidelines for the screening, treatment, and surveillance of CRC exist. While surgery can be a potentially curative modality even in patients with metastatic disease, comprehensive therapeutic management would entail a multidisciplinary approach, particularly in patients with advanced disease. Precision approaches are of particular interest to improve the efficacy of treatment and achieve better outcomes. Herein, we discuss the commonly involved pathways and actionable therapeutic targets (Table 1). 
Table 1. Common approved targeted therapy for colorectal cancer.

\begin{tabular}{cccc}
\hline Signaling Pathway & $\begin{array}{c}\text { Approved } \\
\text { Targeted Therapy }\end{array}$ & Mechanism of Action & Indication \\
\hline $\begin{array}{c}\text { EGFR } \\
\text { RAS/RAF/ERK }\end{array}$ & $\begin{array}{c}\text { Cetuximab } \\
\text { Panitumumab }\end{array}$ & anti-EGFR MoAb & $\begin{array}{c}\text { RAS/BRAF wt mCRC } \\
\text { (preferred 1st line for } \\
\text { left-sided tumors) }\end{array}$ \\
\hline MMR & $\begin{array}{c}\text { Pembrolizumab } \\
\text { Nivolumab }\end{array}$ & $\begin{array}{c}\text { ICI-Anti PD-1 MoAb } \\
\text { Anti PD-1 MoAb }\end{array}$ & dMMR/MSI-H mCRC \\
\hline RAS/RAF/ERK & Encorafenib & BRAF kinase inhibitor & $\begin{array}{c}\text { mCRC with BRAF } \\
\text { V600E mutation }\end{array}$ \\
\hline VEGF & $\begin{array}{c}\text { Bevacizumab } \\
\text { Regorafenib } \\
\text { Ramucirumab } \\
\text { Aflibercept }\end{array}$ & $\begin{array}{c}\text { anti-VEGF MoAb } \\
\text { anti-VEGF-R } \\
\text { anti-IgG1 MoAb } \\
\text { Recombinant fusion } \\
\text { (VEGFR-1/2 \& IgG1) }\end{array}$ & $\begin{array}{c}\text { (Bev.) first-line regimen for } \\
\text { unresectable metachronous } \\
\text { mCRC; mCRC which has } \\
\text { progressed with } \\
\text { standard treatment }\end{array}$ \\
\hline EGFR 2 (HER2) & $\begin{array}{c}\text { Trastuzumab } \\
\text { Lapatinib }\end{array}$ & $\begin{array}{c}\text { Anti-HER2 MoAb } \\
\text { TKI (anti-EGFR1/HER2) }\end{array}$ & $\begin{array}{c}\text { HER2-overexpressed } \\
\text { CRC after failing 1st line }\end{array}$ \\
\hline
\end{tabular}

Abbreviations: MoAb: monoclonal antibody; TKI: tyrosine kinase inhibitor; ICI: immune checkpoint inhibitor; mCRC: metastatic colorectal cancer; MMR: mismatch repair; BRAF: v-raf murine sarcoma viral oncogene homologB1; dMMR/MSI-H: deficienct mismatch repair, microsatellite instability high; VEGF: vascular endothelial growth factor; HER2: Human epidermal growth factor receptor 2; Bev.: bevacizumab.

\section{Signaling Pathways and Therapeutic Targets}

\subsection{RAS and EGFR}

The rat sarcoma (RAS) genes (including KRAS and NRAS) are a family of oncogenes that have been linked to the development of CRC in both adenoma-carcinoma sequence and serrated models $[10,14]$. Overexpression of epidermal growth factor receptor (EGFR) has been identified in $49-80 \%$ of CRC, and RAS mutations have been identified as a predictor of poor response to anti-EGFR mAb treatment in mCRC [15-18]. Both the National Comprehensive Cancer Network (NCCN, www.ncen.org) and American Society of Clinical Oncology (ASCO, www.asco.org) guidelines suggest that all mCRC should be tested for extended RAS mutation in a certified laboratory and detection of specific mutations would preclude them from anti-EGFR treatment $[4,19,20]$. It has been suggested that extended RAS testing may be helpful in guiding therapy choices. For example, Neuroblastoma RAS viral oncogene homolog (NRAS) and Kirsten rat sarcoma viral oncogene homolog (KRAS) exon $2 \mathrm{wt}$ are associated with improved progression-free survival (PFS) and overall survival (OS) with anti-EGFR treatment in addition to chemotherapy [21]. Furthermore, wt status in regard to other biomarkers, including BRAF/PIK3CA in addition to KRAS and NRAS (so called "quadruple negative tumors"), has been demonstrated to have favorable effects in regard to anti-EGFR $m A b$ response [22]. However, in patients with $R A S$ wild-type $(w t)$ tumors, the data supports anti-EGFR $\mathrm{mAb}$ as an effective adjunct in the treatment of $\mathrm{mCRC}$ as described below.

Multiple studies have examined these agents in use with irinotecan-based chemotherapy regimens, as anti-EGFR $\mathrm{mAb}$ were postulated to provide benefit to irinotecan-resistant $\mathrm{mCRC}$ in human colorectal xenografts [23].

Clinical applications of these findings include the CRYSTAL trial, a phase III study, which showed improved response rate (RR) (RR of $65.2 \%$ with the addition of cetuximab compared to $38.6 \%$ ), PFS (increased by 3 months with the addition of cetuximab; 11.4 months compared to 8.4 months) and median overall survival (OS) (an increase in OS by over 8 months with the addition of cetuximab; 28.4 months compared to 20.2 months) with the first-line treatment of mCRC in patients with RAS wt tumors [24]. The post hoc evaluation of the study extending RAS mutation showed that there may be benefits to the addition of cetuximab if RAS mutation signals were less than $5 \%$ [24]. The phase III EPIC trial showed that the combination of irinotecan and cetuximab in comparison to irinotecan alone improved quality of life, increased PFS (median PFS increased by 1.4 months; 4 months with the 
addition of cetuximab compared to 2.6 months) and RR (RR 16.4\% with the addition of cetuximab, compared to RR of $4.2 \%$ ), but no difference in OS (10.7 months with cetuximab compared to 10.0 months) in patients who previously failed first-line systemic treatment of mCRC [25]. Another phase III study, the BOND trial, showed improved RR (RR was $12.1 \%$ higher with combination therapy; $22.9 \%$ versus $10.8 \%$ ) and time to progression (time to progression was 2.6 months longer with combination therapy; 4.1 months versus 1.5 months), with a trend towards increased median survival (8.6 months with combination therapy versus 6.9 months, not a statistically significant finding) in patients treated with combination cetuximab and irinotecan compared to cetuximab monotherapy [26]. In regard to targeted anti-EGFR treatment in use with oxaliplatin-based regimens, a phase III trial carried out by Douillard et al. showed improved PFS (PFS increased by 2.2 months with the addition of panitumumab; 10.1 months versus 7.9 months) and OS (OS increased by 5.8 months with the addition of panitumumab; 26 months compared to 20.2 months) with FOLFOX and panitumumab in comparison to FOLFOX alone after a post hoc evaluation with extending KRAS mutations [27,28]. The phase II OPUS trial compared treatment of mCRC with FOLFOX-4 versus FOLFOX-4 plus cetuximab and found improved PFS (hazard ratio (HR) 0.567, $p=0.0064$ ); however, there was no significant effect on OS (HR 1.015, 95\% CI 0.791-1.303, $p=0.91$ ) [29]. These findings were echoed in the phase III PRIME trial, in which patients were treated with either FOLFOX-4 or FOLFOX-4 plus panitumumab and investigators found improvements in PFS and a trend towards improvement in OS in a subset of KRAS wt patients only (median PFS 10.0 months versus 8.6 months, $p=0.01$ and median OS 23.9 months versus 19.7 months, $p=0.17$ ) [28]. Similarly, the TAILOR trial, also a phase III study, demonstrated improved RR (RR increased by $21.6 \%$ with the addition of cetuximab; $61.1 \%$ versus $39.5 \%$ ), PFS (improved by 1.8 months with the addition of cetuximab; 9.2 months compared to 7.4 months) and OS (OS increased by 2.9 months with the addition of cetuximab; 20.7 months compared to 17.8 months) with FOLFOX plus cetuximab versus FOLFOX alone in patients with RAS and BRAF wt disease [30].

Different clinical variables can determine the appropriateness of anti-EGFR treatment. The benefits of this modality differ in regard to use in the neoadjuvant setting of resectable versus unresectable mCRC as well as primary tumor laterality. Anti-EGFR mAbs have benefits in unresectable metachronous CRC metastases (in combination with FOLFIRI or irinotecan) in patients who are proven to have $R A S$ wt disease and these data have informed the NCCN guidelines [4,14,31-33]. In contrast, the New EPOC trial showed worse outcomes in mCRC patients who were KRAS wt, including a significantly shorter PFS (PFS 14.1 months with the addition of cetuximab compared to 20.5 months) and a trend towards worse median OS (median OS was 39.1 months with the addition of cetuximab, median OS was not reached with chemotherapy alone, but this finding was not statistically significant) in mCRC patients with resectable hepatic metastases treated with chemotherapy and cetuximab compared to chemotherapy alone in the neoadjuvant setting [34]. One potential bias of this study is that only KRAS wt (and not all RAS wt) patients were included. Furthermore, findings of the CAPRI trial demonstrated improved progression-free survival (PFS) in RAS wt mCRC patients treated with anti-EGFR mAb by almost 2 months (PFS of 6.4 months in patients who were treated with cetuximab and FOLFOX compared to 4.5 months with FOLFOX alone) [32].

Furthermore, while resistance to targeted EGFR $\mathrm{mAb}$ is well documented in cases of $R A S$ mutations, several other biomarkers are associated with EGFR resistance. Specifically, BRAFV600E, MET, MEK, PIK3CA, PTEN and HER2 are linked to innate EGFR resistance in $\mathrm{mCRC}$ [35]. There are also data that show that resistance to EGFR treatment can be acquired de novo [22,36]. Acquired EGFR resistance continues to be a topic of investigation, and SHP2 has been studied as a target in patients with EGFR resistance in non-small cell lung cancer (NSCLC) [37]. Other studies have identified various targets DUSP4, ETV5, GNB5, NT5E, PHLDA as markers to overcome EGFR resistance [38]. MEK inhibitors, MET inhibitors, KRAS mutant inhibitors and other drugs have been investigated as potential options to combat anti-EGFR resistance [35,39,40]. Liquid biopsy can be used to detect developing EGFR resistance before it is clinically or radiographically evident [40,41]. Ongoing studies continue to elucidate EGFR resistance and the role of biomarkers in this phenomenon. 
Mounting evidence suggests that left-sided primary CRC benefits most from treatment with anti-EGFR mAb. In a review of the literature, Sandhu and colleagues found that mCRC patients with $R A S$ wt left-sided lesions, in particular, have improved RR (RR ranging 66.4-72.5\% with the addition of anti-EGFR $\mathrm{mAb}$ treatment compared to RR ranging 40.6-52.6\% with chemotherapy alone), PFS (PFS ranging 9.2-12.9 months with the addition of anti-EGFR mAb treatment compared to PFS ranging 7.6-9.2 months with chemotherapy alone), and OS (OS ranging 22-30.3 months with the addition of anti-EGFR $m A b$ treatment compared to OS ranging 18.7-23.6 months with chemotherapy alone) with anti-EGFR mAb treatment [33]. Similarly, the CALGB/SWOG 80405 trial showed overall improved outcomes, especially in left-sided primary KRAS wt CRC with improved OS (OS for all-sided lesions was 30 months with cetuximab plus chemotherapy versus 29 months with bevacizumab plus chemotherapy, the finding was not statistically significant) in this population $[42,43]$. Conversely, PFS (PFS after treatment with cetuximab for left-sided lesions was 12 months versus 7.7 months for right-sided lesions) and OS (OS after treatment with cetuximab for left-sided lesions was 37.5 months versus 16.4 months for right-sided lesions) were shorter in KRAS wt patients with right-sided primary CRC who were treated with cetuximab [43]. Interestingly, neither PFS nor OS was improved with the addition of cetuximab compared to bevacizumab without controlling for KRAS wt status [43].

While KRAS mutations play an important role in decision making for other targeted therapies, $K R A S$ inhibitors have not yet been well established for targeted therapy. Hong et al. examined the use of sotorasib (a KRAS p.G12C mutant inhibitor) in patients with advanced non-small cell lung cancer (NSCLC), CRC and other solid tumors and reported improved objective response rate (ORR) and disease control (defined as at least partial RR or stable disease) [39]. While their findings were most remarkable in the NSCLC cohort, the CRC cohort did have a disease control rate of $73.8 \%(95 \% \mathrm{CI}$ 57.96-86.14\%) and a median PFS of 4 months (range 0-11.1 months) [39]. This study is important, as it revealed a clinical benefit in a prospective study at this scale for the first time. While KRAS G12C is not a common mutation in colorectal cancer, this study is significant in demonstrating treatment efficacy for KRAS inhibitors. Other KRAS inhibitors are under investigation in clinical trials.

\subsection{Microsatellite Instability (MSI), Mismatch Repair (MMR), and Immune Checkpoint Inhibitors}

Deficiency in MMR genes (dMMR) is a known risk factor for $C R C$ as a result of multiple successions of genetic mutations. In this pathway, CRC develops as a result of the inactivation of DNA mismatch repair genes, including $M S H 2, M S H 6$, and $M L H 1$, which leads to the accumulation of multiple mutations in long repetitive sequences of short DNA fragments (termed microsatellite), and subsequent microsatellite instability [44]. Microsatellite instability (MSI-H) is detected in up to $17 \%$ of sporadic CRC, and both MSI-H and MMR are associated with HNPCC [44]. There is heterogeneity within the CRC associated with $\mathrm{dMMR}$ and MSI-H, and these differences have been investigated and divided into four subgroups (CMS1, CMS2, CMS3, and CMS4) based on molecular features [45]. MSI-H, which is associated with $\mathrm{CRC}$, confers better prognosis and is associated with a proximal location within the colon, mucinous or signet ring histopathology, and less likelihood of invasion [44]. Furthermore, MSI-H and dMMR have implications for CRC treatment, particularly in the adjuvant setting [44,46]. Further analysis of outcome data from the QUASAR trial by Hutchins et al. demonstrated improved prognosis and lower risk of recurrence of CRC in patients with $\mathrm{dMMR}$, with an $11 \%$ recurrence rate in dMMR, compared to a $26 \%$ recurrence rate in patients with no mutations or deficiencies in MMR; nonetheless, it was not predictive of chemotherapy response $[47,48]$. Data from the NSABP C-07 trial support these conclusions and found that $\mathrm{dMMR}$ status had a favorable prognosis for recurrence (hazard ratio (HR) $0.48,95 \%$ CI $0.33-0.70, p<0.0001$ ) and improved OS (HR 0.63, 95\% CI 0.46-0.89, $p=0.0084)$ in CRC, although there was also demonstrable worse survival after recurrence in patients with dMMR (HR 1.60, 95\% CI 1.07-2.41, $p=0.02$ ) [49]. Data from the NSABP C-07 trial were not able to predict responses to systemic oxaliplatin [49].

Sargent et al. investigated five randomized control trials in which stage II or stage III CRC patients received surgery with or without adjuvant fluorouracil (FU)-based chemotherapy postoperatively [50]. 
Patients without MMR mutations or deficiencies had higher disease-free survival (DFS) after adjuvant treatment with FU-based adjuvant therapy in comparison to dMMR patients (HR 0.67, 95\% CI 0.48-0.93, $p=0.02$ ), and these were statistically significant findings [50]. Interestingly, bevacizumab, an anti-VEGF $\mathrm{mAb}$, was shown to have a survival benefit when used in combination with standard therapy for the treatment of CRC in patients with known dMMR (HR 0.52, 95\% CI =0.29-0.94, $p=0.02)$ [51]. Additionally, MMR mutations are known to affect immune checkpoint proteins PD1, PDL1, CTLA-4, LAG-3, and IDO and these have been investigated as possible immunotherapy targets [52].

Multiple immune checkpoint markers, including PD1, are of great interest as drug targets in melanoma, renal cell carcinoma, small and non-small cell lung cancer, Hodgkin lymphoma, bladder cancer and other malignancies [53]. Currently, multiple phase II studies are showing promising results for the use of anti-PD1 mAb in treatment of $\mathrm{mCRC}$ and the NCCN currently recommends treatment of unresectable metachronous CRC metastases with pembrolizumab or nivolumab in patients with dMMR or MSI-H tumors [4]. The Checkmate-142 trial, a phase II study that examined the use of nivolumab in $74 \mathrm{mCRC}$ patients with dMMR or MSI-H, showed a $31.1 \%$ overall response rate, with $34.8 \%$ having a response for over a year and $68.9 \%$ had control of the disease for at least 12 weeks [54]. Le et al. found that treatment with pembrolizumab in patients with dMMR resulted in a RR of $40 \%$ (versus $0 \%$ ) and immune-related PFS of 78\% (versus 11\%) in comparison to those without MMR deficiency [55]. The KEYNOTE-164 trial, and Furmet et al. investigated the use of other checkpoint inhibitors (anti-PDL1 and anti-CTLA4) [56,57]. The KEYNOTE-164 trial examined the use of pembrolizumab in adults with dMMR or MSI-H mCRC who were previously treated with at least two (cohort A) or one (cohort B) other forms of standard therapy [56]. ORR was 33\% in both cohorts, the median PFS was 2.3 months (cohort A) versus 4.1 months (cohort B), while median OS was 31.4 months (95\% CI 21.4 months not reached in cohort A) and not reached in cohort B (95\% CI 19.2 months not reached), and thus demonstrating more durable responses in less pretreated patients [56]. KEYNOTE-177 is an important phase 3 multicenter, randomized controlled trial that investigated the use of first-line immune checkpoint blockade with pembrolizumab (versus investigator's choice of standard chemotherapy) in patients with dMMR mCRC [58]. Investigators found a statistically significant improvement in PFS with pembrolizumab compared to chemotherapy (median PFS 16.5 compared to 8.2 months, HR 0.60, 95\% CI 0.45-0.80, $p=0.0002$ ) [58]. Awaiting publication of the final KEYNOTE-177 results, the U.S. Food and Drug Administration (FDA) has approved pembrolizumab for first-line use in dMMR/MSI-H mCRC based on these findings [59]. Collectively, these data support testing for dMMR in patients with CRC and demonstrate the variable efficacy of systemic treatment, including standard chemotherapy targeted anti-PD1 agents, in selected dMMR patients. Recent and ongoing trials investigating the use of immune checkpoint inhibitors in the treatment of CRC are summarized in Tables 2 and 3 [53-56,59-62].

Despite these findings, several challenges remain in the realm of clinical applications for immune checkpoint inhibitors in mCRC treatment, particularly in microsatellite stable disease (MSS). It is postulated that MSS CRC has an inherent resistance to immune checkpoint blockade, and several investigators have outlined the difficulties in applying immune checkpoint inhibitor therapy to a wider population of $\mathrm{mCRC}$ patients with MSS disease secondary to intrinsic resistance of MSS disease to immune checkpoint blockade [62,63]. Several toxicities and adverse events are associated with immune checkpoint inhibitors. These side effects are often immune-related adverse events (irAE) and inflammatory reactions in different organs and systems ("itis"), including gastrointestinal tract, respiratory, endocrine, skin and musculoskeletal irAEs. Manifestations include fatigue, diarrhea, rash, elevated lipase/amylase, hepatitis, diabetes, pneumonitis and colitis [54]. While the future of immune checkpoint inhibitors remains promising for patients with dMMR/MSI mCRC, the search for therapeutic immune checkpoint options and finding methods to convert immunologically "cold" tumors to "hot" tumors and responders to immunotherapy in patients with proficient MMR and microsatellite stable $\mathrm{mCRC}$ remains ongoing. 
Table 2. Recent trials involving checkpoint inhibitors in metastatic colorectal cancer (mCRC) treatment.

\begin{tabular}{|c|c|c|c|}
\hline Study & NCT02060188 (Checkmate-142) * & NCT01876511* & NCT02460198 (KEYNOTE-164) * \\
\hline Phase & II & II & II \\
\hline Population & $\begin{array}{l}74 \text { recurrent or metastatic CRC patients with } \\
\text { confirmed dMMR or MSI-H }\end{array}$ & $\begin{array}{l}41 \text { patients with progressive mCRC regardless of } \\
\text { MMR/MSI status or patients with other metastatic } \\
\text { carcinoma known to have dMMR or MSI-H }\end{array}$ & $\begin{array}{l}124 \mathrm{mCRC} \text { patients with confirmed dMMR or } \\
\text { MSI-H, cohort A was treated with } \geq 2 \text { prior } \\
\text { therapies, cohort } \mathrm{B} \text { treated with } \geq 1 \text { prior therapy }\end{array}$ \\
\hline Treatment arms, prescribed regimen(s) & Nivolumab $3 \mathrm{mg} / \mathrm{kg}$ every 2 weeks & Pembrolizumab $10 \mathrm{mg} / \mathrm{kg}$ every 2 weeks & $\begin{array}{c}\text { Pembrolizumab } 200 \mathrm{mg} \text { every } 3 \text { weeks for up to } \\
2 \text { years }\end{array}$ \\
\hline Primary endpoint(s) & Objective response rate (ORR) & ORR and PFS & ORR \\
\hline $\begin{array}{l}\text { Response rate, progression free survival } \\
\text { and overall survival }\end{array}$ & $\begin{array}{l}\text { ORR } 68.9 \% \text {, PFS } 50 \% \text { at } 12 \text { months, OS } 73.4 \% \text { at } \\
12 \text { months }\end{array}$ & $\begin{array}{l}\text { ORR } 40 \% \text {, median PFS and median OS not reached } \\
\text { at } 12 \text { months in dMMR/MSI-H mCRC patients }\end{array}$ & $\begin{array}{l}\text { ORR } 33 \% \text { for both cohorts, median PFS was } 2.3 \\
\text { months (cohort A) and } 4.1 \text { months (cohort } \mathrm{B} \text { ), } \\
\text { median OS was } 31.4 \text { months (cohort A) and not } \\
\text { reached at } 27 \text { months in cohort B }\end{array}$ \\
\hline Grade 3 and 4 adverse events & Elevated lipase (8.1\%), elevated amylase (2.7\%) & $\begin{array}{l}\text { Rash/pruritus ( } 24 \%) \text {, hypothyroidism or other } \\
\text { thyroid concerns }(10 \%) \text {, pancreatitis }(15 \%)\end{array}$ & $\begin{array}{l}\text { Grade } 3-4 \text { adverse events ( } 16 \% \text { cohort A, } 13 \% \\
\text { cohort B) including colitis, hepatitis, pancreatitis, } \\
\text { pneumonitis, skin reactions, arthralgias, asthenia } \\
\text { and fatigue }\end{array}$ \\
\hline Other significant findings & $\begin{array}{l}\text { Patients with at least partial response had } 12.8 \% \\
\text { greater decline in CEA level compared to patients } \\
\text { with stable disease }\end{array}$ & $\begin{array}{l}\text { There was a mean of } 1782 \text { somatic mutations per } \\
\text { tumor in patients with dMMR or MSI-H }\end{array}$ & $\begin{array}{c}18 \% \text { (cohort } \mathrm{A} \text { ) and } 11 \% \text { (cohort B) of participants } \\
\text { had } R A S / B R A F \text { wt tumors }\end{array}$ \\
\hline
\end{tabular}

* ClinicalTrials.gov Identifier 
Table 3. Ongoing trials involving checkpoint inhibitors in mCRC treatment.

\begin{tabular}{|c|c|c|c|}
\hline Study & NCT03202758* & NCT04262687 * & NCT03832621* \\
\hline Phase & $\mathrm{I} / \mathrm{II}$ & II & II \\
\hline Condition/Disease/Population & $\begin{array}{c}\text { Will include mCRC } 48 \text { patients with microsatellite } \\
\text { stable (MSS), RAS mutant tumors. Actively recruiting } \\
\text { and data not yet available }\end{array}$ & $\begin{array}{l}\text { microsatellite stable mCRC patients with high } \\
\text { immune infiltrate }\end{array}$ & Microsatellite stable, MGMT silenced mCRC \\
\hline Intervention & $\begin{array}{l}\text { Phase I: Durvalumab } 750 \mathrm{mg} \text { every } 2 \text { weeks plus } \\
\text { Tremelimumab } 75 \mathrm{mg} \text { every } 4 \text { weeks plus FOLFOX } \\
\text { during the } 2 \text { first cycles of treatment ( } 1 \text { month) } \\
\text { Phase II: Durvalumab } 750 \mathrm{mg} \text { every } 2 \text { weeks plus } \\
\text { Tremelimumab } 75 \text { mg every } 4 \text { weeks plus FOLFOX }\end{array}$ & $\begin{array}{l}\text { Drug: Capecitabine } 2000 \mathrm{mg} / \mathrm{m}^{2} / \text { day, from day } 1 \text { to } 14 \\
\text { of each cycle, Drug: Oxaliplatin } 130 \mathrm{mg} / \mathrm{m}^{2} \text { by IV } \\
\text { infusion over } 2 \mathrm{~h} \text {, on day } 1 \text { of each cycle, Drug: } \\
\text { Bevacizumab } 7.5 \mathrm{mg} / \mathrm{kg} \text { by IV infusion over } 60 \mathrm{~min}, \\
\text { on day } 1 \text { of each cycle, Drug: Pembrolizumab } 200 \mathrm{mg} \\
\text { by IV infusion over } 30 \mathrm{~min} \text {, on day } 1 \text { of each cycle }\end{array}$ & $\begin{array}{c}\text { Drug: Temozolomide } 150 \mathrm{mg} / \mathrm{sqm} \text { daily on days } \\
\text { 1-5 every } 4 \text { weeks, Drug: Nivolumab } 480 \mathrm{mg} \text { IV } \\
\text { every } 4 \text { weeks, Drug: Ipilimumab (low-dose) } \\
1 \mathrm{mg} / \mathrm{Kg} \text { IV every } 8 \text { weeks }\end{array}$ \\
\hline Endpoints & Safety (after Phase I) and Efficacy (after Phase II) & $\begin{array}{l}\text { Assessing efficacy of pembrolizumab in combination } \\
\text { with xelox and bevacizumab as first-line treatment for } \\
\text { microsatellite stable (non MSI-H) mCRC }\end{array}$ & $\begin{array}{l}\text { 8-month PFS after treatment with combination } \\
\text { of temozolomide, nivolumab and ipilimumab }\end{array}$ \\
\hline Enrollment (total, open: yes/no) & 48, Yes & 55 , Not yet & 100, Yes \\
\hline
\end{tabular}

${ }^{*}$ ClinicalTrials.gov Identifier. 


\subsection{BRAF}

V-raf murine sarcoma viral oncogene homolog b1 (BRAF) is a proto-oncogene involved in the MAPK signaling cascade and is a downstream effector of EGFR (along with RAS) [64-66]. Interestingly, inhibition of $B R A F$ has been associated with over-activation of EGFR, which is postulated to cause the attenuated response of vemurafenib observed in in-vitro mCRC [46]. BRAF V600E activating mutation has been implicated in the development of CRC and is present in approximately $15 \%$ of cases of sporadic CRC, and portends a worse prognosis $[1,14,64]$. BRAF has been investigated and developed as a drug target (i.e., vemurafenib) and has been used with success in the treatment of melanoma [14]. The NSABP C-07 trial showed that BRAF mutations in CRC were also associated with dMMR, advanced age, a trend towards higher $\mathrm{T}$ stage, and decreased survival after recurrence (HR 2.31, 95\% CI 1.83-2.95, $p<0.0001$ ), and worse OS (HR 1.46, 95\% CI 1.20-1.79, $p=0.0002$ ) [49]. Similar to the NSABP C-07 results regarding MMR status and response to adjuvant therapy, BRAF mutations were not a significant predictor in response to oxaliplatin [49]. Of note, it is well established that $B R A F$ mutations clinically translate to lack of response to anti-EGFR mAb in KRAS wt mCRC patients and the NCCN recommends $B R A F$ testing for all patients with $\mathrm{mCRC}$ to assess appropriate candidates for anti-EGFR $m A b$ treatment in this population $[4,66-68]$.

These findings have led to studies investigating the efficacy of combining anti-BRAF and anti-EGFR agents as a means of circumventing poor response to existing therapeutic regimens. A pilot study by Yaeger et al. showed that anti-BRAF therapy (vemurafenib) was tolerated well when combined with panitumumab in BRAF V600E mutant mCRC patients who had disease progression on standard therapy [69]. A phase 1B study by Hong and colleagues similarly showed that a combined regimen of vemurafenib, irinotecan and cetuximab was well tolerated in $\mathrm{mCRC}$ patients with BRAF mutations [70]. The recent S1406 phase II trial investigating the efficacy of combined cetuximab, irinotecan, and vemurafenib compared to cetuximab and irinotecan alone has completed accrual and preliminary results showed an increased PFS (4.3 months with the addition of vemurafenib versus 2.0 months with cetuximab and irinotecan alone); nonetheless, these findings were not statistically significant [71]. Addition of encorafenib (a BRAF inhibitor) with or without binimetinib (a MEK inhibitor, with effectors downstream of $B R A F$ ) in addition to cetuximab significantly improved OS (OS 9 months with triplet therapy versus 5.4 months) in comparison to treatment with cetuximab plus chemotherapy in the phase III BEACON trial [72]. Updated results of the BEACON trial demonstrate similar OS with either the triplet or doublet chemotherapy combinations (median OS 9.3 months, $95 \%$ CI 8.2-10.8; versus 9.3 months, $95 \%$ CI 8.0-11.3) for triplet and doublet chemotherapy, respectively, and with higher rates of adverse events in the triplet therapy group compared to doublet therapy (65.8\% versus $57.4 \%$ ) [73]. While the findings regarding V600E mutant $\mathrm{mCRC}$ have clinical implications for anti-BRAF therapy, non-V600E BRAF mutations in mCRC patients have been demonstrated to predict poor response to anti-EGFR therapy [74,75]. Furthermore, V600E mutant CRC has been associated with older age, right-sided laterality, poorly differentiated status and advanced disease stage vs. non-V600L mutant CRC, which is associated with left-sided primary tumor location and well-differentiated histology [74].

\subsection{VEGF}

Vascular endothelial growth factor (VEGF) is known to promote angiogenesis, leading to increased tumor growth secondary to more robust vascular supply [76]. Bevacizumab, an anti-VEGF mAb, is currently part of an NCCN recommended first-line regimen for unresectable metachronous mCRC (in combination with standard chemotherapeutic regimens) [4].

The addition of bevacizumab was shown to increase RR (RR $44.8 \%$ compared to $34.8 \%$ ), response duration (median duration of response 10.4 months compared to 7.1 months), PFS (median duration of PFS 10.6 months compared to 6.2 months) and OS (median duration of survival 20.3 months with the addition of bevacizumab compared to 15.6 months) when used in combination with systemic chemotherapy patients with mCRC in the phase III AVF2107 trial [77]. These findings were replicated 
in the phase III ARTIST trial, which showed significantly increased objective RR (objective RR 35.3\% with the addition of bevacizumab compared to 17.2\%), PFS (median PFS 8.3 months versus 4.2 months) and OS (OS 18.7 with the addition of bevacizumab compared to 13.4 months) when bevacizumab was added to irinotecan, leucovorin, and 5-FU as first-line therapy [78]. Another phase III study, the TRIBE trial, demonstrated the efficacy of bevacizumab with FOLFIXIRI with a demonstrably higher early tumor shrinkage rate, RR (objective RR 65\% versus 53\%) and PFS (PFS 12.1 months versus 9.7 months) in the experimental group treated with FOLFOXIRI plus bevacizumab compared to the control group treated with bevacizumab plus FOLFIRI $[79,80]$. The BRiTE study, a phase IV prospective cohort study, also supported the use of bevacizumab as a first-line adjunct in mCRC treatment [81]. The addition of bevacizumab to FOLFOX4 improved median duration of survival (12.9 months versus 10.8 months, $p=0.0011$ ) and 1 year survival (56\% versus $43 \%, p<0.0001)$ [82]. It should be noted that there are also data on mCRC treated with oxaliplatin-based chemotherapy plus bevacizumab as a first-line regimen, which show that PFS may be significantly improved, and OS may not be significantly improved [83]. These findings and the observations from similar investigations have solidified the role of anti-VEGF $\mathrm{mAb}$ as part of a first-line regimen for the treatment of unresectable mCRC. Toxicity is an important adverse clinical outcome, which has also been well described in the literature. The BEAT study assessed the safety of bevacizumab with the physician's choice of standard chemotherapy and found the most common grade three or greater adverse events were neutropenia, neuropathy, bleeding, gastrointestinal perforation, hypertension, thromboembolic events, proteinuria and poor wound healing [84,85]. Furthermore, genetic analysis of polymorphisms in ERCC1, XPD and GSTP1 did not show any effect on the safety or efficacy of bevacizumab in combination with standard chemotherapy for mCRC [85].

Although bevacizumab is the most widely investigated anti-VEGF agent and is currently recommended by the NCCN as the preferred anti-VEGF mAb considering its more favorable cost and side-effect profile, other anti-VEGF agents, including aflibercept (an anti-VEGF fusion protein) and ramucirumab (an anti-VEGFR2 $\mathrm{mAb}$ ) have been studied and are acceptable alternatives in the first-line treatment of unresectable metachronous CRC metastases [4]. These alternative anti-VEGF agents have also been studied as the next-line adjuncts after treatment failure. The VELOUR trial, a phase III study, showed improvement in RR (RR 19.8\% with the addition of aflibercept compared to $11.1 \%$ ), PFS (median PFS 6.9 months with the addition of aflibercept compared to 4.7 months), and OS (median OS 13.5 months with the addition of aflibercept compared to 12.1 months) in mCRC patients who had disease progression on or after treatment with standard therapy when treated with aflibercept and FOLFIRI in comparison to FOLFIRI alone as second-line treatment [86]. Similarly, the phase III RAISE trial showed improved overall survival in mCRC patients with disease progression on first-line therapy who received ramucirumab plus FOLFIRI in comparison to FOLFIRI alone as second-line treatment [87]. The success of these newer anti-angiogenesis agents in the second-line setting has set the stage to assess their role as potential first-line therapy options in the future [87-89].

The multi-kinase inhibitor regorafenib, with activity against VEGF, now has FDA approval for mCRC, which has progressed with standard treatment. In the phase III CORRECT trial on regorafenib, median OS was improved with regorafenib monotherapy compared to placebo (6.4 months versus 5.0 months, $p=0.0052$ ) [89]. Interestingly, in the IMblaze370 study, median OS did not significantly differ between $\mathrm{mCRC}$ patients treated with atezolizumab plus cobimetinib or atezolizumab monotherapy versus regorafenib as third-line therapy [90]. Clinical application of anti-VEGF in mCRC remains a challenging obstacle due to a lack of clinically significant biomarkers, which has limited its application with regard to treatment. A recent study has identified Tie2, a tumor vasculature marker, as a relevant clinical marker to monitor anti-VEGF use [91]. In comparing use of standard chemotherapy combined with either bevacizumab or cetuximab in the FIRE-3 trial, there was no significant difference in objective RR (odds ratio 1.18, 95\% CI 0.85-1.64, $p=0.18$ ) or median PFS (HR 1.06, 95\% CI 0.88-1.26, $p=0.55$ ) but there was a significantly higher median OS in the cetuximab group compared to bevacizumab (28.7 versus 25.0 months, $p=0.017$ ) [92]. A similar study by Venook et al. also studied the addition of 
cetuximab versus bevacizumab in chemotherapy, and while there was a trend towards improved OS with cetuximab, this finding was not statistically significant (30.0 months versus 29.0 months $p=0.08$ ) in KRAS wt patients [42].

\subsection{HER2}

Human epidermal growth factor receptor 2 (HER2) plays a role as an oncogene in several solid organ cancers, including breast, lung and ovarian cancer, and has been successfully used as a therapeutic target (i.e., trastuzumab). While studies have failed to support any prognostic value for overexpression of HER2 in CRC, it is present in up 14-81\% of CRC cases and HER2 overexpression has also been demonstrated to be predictive of resistance to anti-EGFR treatment [93,94]. The recent phase IIa MyPathway study showed a RR of 32\% in refractory mCRC patients with HER2 amplification treated with dual anti-HER2 agents trastuzumab and pertuzumab [95]. Similarly, the HERACLES trial, a phase II study, similarly examined dual anti-HER2 treatment with trastuzumab and lapatinib in KRAS wt mCRC patients with HER2 overamplification who were refractory to prior therapies and found a RR of 30\% [96]. The HERACLES-B trial expanded on these findings and examined the use of trastuzumab-emtansine in patients with RAS/BRAF wt, HER2 amplified mCRC with the progression of disease after treatment with anti-EGFR therapy and found objective RR of 10\% (95\% CI 0-28\%) and median PFS of 4.8 months (95\% CI 3.6-5.8 months) [97]. The current HERACLES-RESCUE trial is examining the use of trastuzumab-emtansine in patients with HER2 amplified mCRC, which has progressed with lapatinib and trastuzumab treatment [98]. Similarly, the DESTINY CRC01 trial is examining the use of trastuzumab-deruxtecan in patients with HER2 amplified mCRC [99]. Ongoing phase III studies are designed to further elucidate the role of anti-HER2 therapies in the treatment of CRC; nonetheless, routine assessment of HER2 is not recommended in the management of metastatic CRC.

\section{6. $P I 3 K C A$}

Phosphatidylinositol 3-kinase catalytic subunit alpha (PI3KCA) is a downstream effector of the EGFR as well as RAS and operates parallel to BRAF and has been identified in up to $25 \%$ of CRC $[49,100]$. Current evidence suggests that PI3KCA mutations render anti-EGFR mAb treatment of CRC ineffective with lower response rates and is associated with worse outcomes overall [101-104]. As the downregulation of COX2 is shown to inhibit PI3K signaling, an emerging potential therapeutic role has been suggested for aspirin [105]. Liao et al. demonstrated that patients with PI3KCA mutations who regularly took aspirin after CRC diagnosis had significantly longer cancer-specific survival at 5 years (HR 0.18, 95\% CI 0.06-0.61, $p<0.001$ ) and overall survival (HR 0.54, 95\% CI 0.31-0.94, $p=0.01$ ) compared to those who did not [105]. A phase II clinical trial was developed to investigate the use of MK-2206, a Protein kinase B (AKT)-inhibitor, in the treatment of PI3KCA mutant, KRAS wt mCRC, which had progressed on standard therapy; however, the trial was closed secondary to lack of accrual, with only one participant [106]. Further evidence is required to demonstrate a survival benefit for ASA use in PI3KCA mutant tumors or PI3KCA targeted drugs.

\section{Novel Therapeutic Modalities}

\subsection{Oncolytic Viruses}

Oncolytic viruses $(\mathrm{OV})$ represent a promising approach to the treatment of various cancers. These viruses harness the body's immune system and recombinant DNA technology to preferentially destroy malignant cells and enhance the anti-tumoral immune response. A variety of viral backbones (herpesvirus, adenovirus, reovirus, etc.) are engineered for tumor cell destruction, leading to multiple cycles of replication, destruction, re-infection, and continued lysis of cancer cells [107]. The most important clinical example of such viruses that have been engineered for oncolysis is talimogene laherparepvec, which was approved by the FDA for melanoma patients, demonstrating an increase in durable RR (16.3\% durable RR with talimogene laherparepvec, compared to $2.1 \%$ durable RR 
with control) and overall RR (26.4\% overall RR with talimogene laherparepvec, compared to $5.7 \%$ overall RR with control). It is under investigation in clinical trials for pancreatic cancer, breast cancer, and hepatocellular carcinoma $[107,108]$. Yang et al. demonstrated the efficacy of an oncolytic herpes simplex virus (HSV) in killing cultured colon cancer cells and colon cancer stem cells [109]. Furthermore, reovirus serotype 3 has been studied in a phase I trial of patients with $\mathrm{mCRC}$ and results suggest that patients mounted an adequate immune response resulting in robust lysis of mCRC cells [110]. Another phase I trial of reovirus serotype 3 has shown to be safe and well-tolerated with FOLFIRI co-treatment in KRAS mutant mCRC patients who had progression of disease on prior chemotherapy [111]. Ongoing trials continue to assess the safety and tolerability of various OVs in the treatment of CRC, but they have not yet succeeded to the advanced phases. Table 4 provides an overview of ongoing trials utilizing oncolytic viruses in the treatment of mCRC [112-116].

Table 4. Ongoing trials investigating oncolytic viruses in metastatic colorectal cancer.

\begin{tabular}{|c|c|c|c|c|c|}
\hline Study & NCT04301011 * & NCT01394939 & NCT01274624 * & NCT03206073 * & NCT03225989* \\
\hline Phase & $\mathrm{I} / \mathrm{II}$ & $\mathrm{I} / \mathrm{II}$ & I & $\mathrm{I} / \mathrm{II}$ & $\mathrm{I} / \mathrm{II}$ \\
\hline Condition/Disease & $\begin{array}{l}\text { Solid tumor, triple } \\
\text { negative breast cancer, } \\
\text { microsatellite stable } \\
\text { colorectal cancer }\end{array}$ & $\begin{array}{l}\text { Metastatic, } \\
\text { refractory } \\
\text { colorectal } \\
\text { carcinoma }\end{array}$ & $\begin{array}{l}\text { KRAS Mutant Metastatic } \\
\text { Colorectal Cancer }\end{array}$ & Colorectal Cancer & $\begin{array}{c}\text { Pancreatic } \\
\text { adenocarcinoma; } \\
\text { Ovarian cancer; Biliary } \\
\text { carcinoma; } \\
\text { Colorectal cancer }\end{array}$ \\
\hline Intervention & $\begin{array}{l}\text { Biological: TBio-6517, } \\
\text { Pembrolizumab }\end{array}$ & $\begin{array}{l}\text { Biological: } \\
\text { JX-594, } \\
\text { Irinotecan }\end{array}$ & $\begin{array}{c}\text { Biological: REOLYSIN, } \\
\text { Drug: Irinotecan, Drug: } \\
\text { Leucovorin, Drug: } \\
\text { Fluorouracil (5-FU), } \\
\text { Drug: Bevacizumab }\end{array}$ & $\begin{array}{c}\text { Biological: } \\
\text { Pexa-Vec, Drug: } \\
\text { Durvalumab, Drug: } \\
\text { Tremelimumab }\end{array}$ & $\begin{array}{c}\text { Drug: Load703 } \\
\text { (oncolytic adenovirus } \\
\text { serotype } 5 / 35 \text { encoding } \\
\text { immunostimulatory } \\
\text { transgenes: TMZ-CD40L } \\
\text { and 41BBL) }\end{array}$ \\
\hline $\begin{array}{l}\text { Enrollment (total, } \\
\text { open: yes/no) }\end{array}$ & 84 , not yet & 52, Completed & 36, Completed & 35 , Open & 50, Open \\
\hline
\end{tabular}

The major clinical challenge with OVs is often efficacy, not safety, and major morbidity and mortality from OV treatments are very rare [117]. Flu-like symptoms are the most common side effects of OV therapy [118]. Oncolytic virus toxicities are generally related to administration, and safety is increased with the administration of a virus with minimal shedding [117]. As an example, for herpes simplex viruses (HSV), latent infection is a concern, but strategies to circumvent this and increase safe use of this family for the development of oncolytic therapies have been described by Campadelli-Fiume et al. [119]. Moreover, the safety advantage for HSV is the availability of antivirals, such as acyclovir, to control unwarranted replication. The majority of OVs pass the phase I safety trials successfully. The major challenge in clinical translation of promising preclinical results has been suboptimal therapeutic efficacy and a lack of durable response. Different strategies are exploited to overcome these challenges and enhance therapeutic efficacy. These strategies include genetic modifications to improve tumor-specific entry targeting and increase oncotropism, enhance viral replication and spread, detarget normal native tissue, and post-entry targeting, and arming OVs with therapeutic genes [120]. The paradigm shift from OVs' cytotoxic features to its immunomodulatory roles in recent years has brought OVs back into the cancer research spotlight [121]. These strategies are employed to enhance the immunomodulatory benefits of OVs. Preclinical findings support an enhanced immunoreactivity of tumors and synergistic tumor toxicity when OVs are combined with various immunotherapies including immune checkpoint inhibitors, which is considered to be a promising approach for the tumors that are not responsive to immune checkpoint inhibitors alone, mainly MSS tumors [122]. While OVs have failed to demonstrate meaningful therapeutic efficacy as a single agent, there are several potential advantages for combination therapy to achieve synergistic tumor-killing effects, which are the subject of several ongoing clinical trials. 


\subsection{CAR T-Cell}

Chimeric antigen receptor T-cell (CAR-T) therapy represents another emerging technology in the treatment of cancer. This treatment modality utilizes modified CAR T-cells to recognize tumor-specific antigens and has been successfully used in the treatment of leukemia and lymphoma but has an increasingly promising role in the treatment of solid organ malignancies as well [123,124]. Zhang et al. demonstrated the safety of carcinoembryonic antigen (CEA) targeted CAR-T in patients with mCRC, notably $70 \%$ of their cohort had stable disease and $20 \%$ had improvement of disease burden as evidenced by cross-sectional imaging after treatment despite prior disease progression on standard therapy [125]. Hege et al. also demonstrated the safety and efficacy of tumor-associated glycoprotein (TAG)-72 targeted CAR-T therapy via systemic intravenous infusion versus hepatic artery infusion in patients with $\mathrm{mCRC}$ and hepatic CRC metastases, respectively [126]. The presence of the TAG-72 targeted CAR-T in the tumor was confirmed with tissue biopsy and serum TAG-72 levels were significantly decreased after CART treatment [126]. Similarly, Yang et al. conducted a phase I trial examining the use of CD133 targeted CAR-T in pancreatic adenocarcinoma, hepatocellular carcinoma and CRC [127]. Within this cohort of patients, $13 \%$ had partial remission, $61 \%$ had stable disease and there was a median PFS of 5 months after treatment [127]. Although the data support the safety of CAR-T in mCRC, subsequent clinical trials on this topic are warranted to evaluate the role of CAR-T as a more mainstream component of CRC treatment. Table 5 provides a summary of existing trials investigating CAR-T in mCRC treatment [128-132].

Table 5. Ongoing trials investigating chimeric antigen receptor T-cells (CAR-T) in colorectal cancer.

\begin{tabular}{|c|c|c|c|c|c|}
\hline Study & NCT03542799* & NCT03692429* & NCT03152435* & NCT04348643* & NCT03638206 * \\
\hline Phase & $\mathrm{I} / \mathrm{II}$ & I & $\mathrm{I} / \mathrm{II}$ & $\mathrm{I} / \mathrm{II}$ & $\mathrm{I} / \mathrm{II}$ \\
\hline Condition Disease & $\begin{array}{c}\text { Metastatic } \\
\text { colorectal } \\
\text { cancer }(\mathrm{mCRC})\end{array}$ & $\begin{array}{l}\text { Colorectal } \\
\text { Cancer }\end{array}$ & $\begin{array}{l}\text { EGFR-positive } \\
\text { Colorectal } \\
\text { Cancer }\end{array}$ & $\begin{array}{c}\text { Solid tumor, lung } \\
\text { cancer, colorectal cancer, } \\
\text { liver cancer, pancreatic } \\
\text { cancer, gastric cancer, } \\
\text { breast cancer }\end{array}$ & $\begin{array}{c}\text { Hematologic malignancies; HCC; } \\
\text { Gastric Cancer; Pancreatic } \\
\text { Cancer; Mesothelioma; } \\
\text { Colorectal Cancer; Esophagus } \\
\text { Cancer; Lung Cancer; Glioma; } \\
\text { Melanoma; Synovial Sarcoma; } \\
\text { Ovarian Cancer; } \\
\text { Renal Carcinoma }\end{array}$ \\
\hline Intervention & $\begin{array}{l}\text { EGFR IL } 12 \\
\text { CAR T-cells }\end{array}$ & $\begin{array}{l}\text { Allogeneic } \\
\text { CAR T-cells, } \\
\text { CYAD-101 }\end{array}$ & $\begin{array}{l}\text { Biological: } \\
\text { EGFR CAR } \\
\text { T-cells }\end{array}$ & $\begin{array}{l}\text { Biological: CEA } \\
\text { CAR-T cells }\end{array}$ & $\begin{array}{l}\text { Biological: CAR-T cell } \\
\text { immunotherapy }\end{array}$ \\
\hline $\begin{array}{l}\text { Enrollment (total, } \\
\text { open: yes/no) }\end{array}$ & 20 , not yet & 36 , yes & 20, unknown & 40 , not yet & 73 , open \\
\hline
\end{tabular}

* ClinicalTrials.gov Identifier.

Despite all the advancements, CAR-T has not shown the same clinical benefit with solid tumors as it has with hematologic malignancies. Several distinct features of solid tumors lead to suboptimal clinical results with the current CAR-T cells. These challenges include the physical barrier, fibrosis and inflammation of the tumor microenvironment, inadequate $\mathrm{T}$ cell trafficking, and genetic heterogeneity with a lack of a universal tumor antigen to target [133,134]. To overcome these challenges, different strategies are being employed. As an example, the construction of co-stimulatory signals (e.g., CD28), expression of domain negative immunosuppressive factors such as IL-10 and TGF-beta, and transgenic cytokine expression (e.g., IL-12) have been considered to enhance immune response, improve trafficking, and reform the microenvironment and inhibit its immunosuppression [135]. In a similar strategy, as discussed with OVs, CAR-T can be engineered to elicit synergistic anti-tumor activity, in combination with conventional and novel therapeutic modalities [136]. Evidence supports enhanced immunotherapeutic efficacy with a combination of immune checkpoint inhibitors and CAR-T [137,138]. Clinical studies are being conducted to investigate them in CRC, including the subset resistant to standard immunotherapy. Moreover, they can be used as a platform to identify patient-specific neoantigens and the $\mathrm{T}$ cell subsets that are most effective in a personalized ex vivo approach. 


\section{Platforms for Personalized Approach}

Cutting edge experimental ex vivo tumoroid platforms, including 3D cultures such as organoids and spheroids, and patient-derived xenografts, offer new and innovative approaches in the treatment of solid tumors such as colorectal cancer. Organoids are patient and/or stem-cell-derived tissue cultures that offer an ex vivo platform to investigate a plethora of diagnostic and therapeutic modalities $[139,140]$. These models have been shown to be a feasible pipeline for drug screening, predicting treatment response, mechanisms of treatment failure, and an overall viable option for investigating novel therapeutic modalities [141,142]. In a prospective study by van de Wetering et al., both normal and tumor tissue was extracted from CRC patients with active disease and the two organoids were compared to evaluate tumor-specific genetic mutations and identify drug sensitivities based on these mutations in a bid to better tailor therapeutic regimens [139]. Kim et al. do note that feasibility concerns may pose an obstacle to more mainstream incorporation of organoid technology in cases of rare genetic alterations; however, they also recognize the benefits of organoids in identifying potential gene-drug interactions; examples include an association between RNF43 mutant tumors and Wnt inhibitors $[139,143]$. Recent studies of colon and appendiceal cancers have demonstrated that organoids can be successfully established in up to $75 \%$ of cases and that organoid response to administered chemotherapeutic treatment is similar to that of response in parent tissue [144,145]. The feasibility of such studies offers hope for future applications of tumor organoids in a bid to drive clinical decision-making on an individualized basis.

Xenotransplantation represents another novel approach in the domain of precision medicine and involves the transplantation of patient-derived tumor tissue into animal models to assess in-vivo response to chemotherapeutic drugs [146]. Understandably, xenotransplantation is both costly and laborious, and it is often limited to more aggressive tumor types, which increases transplantation take rate [147]. Despite these limitations, xenotransplantation still offers an appealing in vivo route for studying clinical outcomes in regard to patient-specific tumors and they offer the opportunity to test newly developed treatment regimens [148].

As a bridge between organoids and xenotransplants, studies have been undertaken to create 3D tumor constructs with the advantage of more closely mimicking an in vivo model in a more controlled manner [147]. Proponents of this technology postulate that this approach allows for better control of the cellular environment than in xenotransplantation and allows for superior applicability than standard 2 dimentionsal (2D) organoids [147,149]. For example, with standard 2D organoid models, colorectal cancer specimens may adopt an epithelial structure that is not representative of the true phenotype in-vivo, leading to differences in signaling pathways, which may impact the effectiveness of tested treatments [149].

Overall, these platforms provide exciting new avenues to transform precision medicine into a personalized approach and explore the genetic heterogeneity of CRC for tangible outcomes in CRC therapies. While these technologies are not yet ready for prime time, clinical investigations are being conducted to evaluate their role in the optimization of the treatments and assessment of their efficacy in improving outcomes in a personalized approach. These efforts will transform the treatment paradigm from a conventional population-based treatment approach into a personalized approach based on the patient-derived platforms that provide predictive tools to guide and enhance treatment efficacy.

\section{Conclusions and Future Directions}

The precision approach, as a crucial component of modern systemic treatment, has substantially improved outcomes of metastatic colorectal cancer. Advancements in unraveling the molecular landscape of CRC and the involved signaling pathways have played an essential role in identifying therapeutic targets and developing novel targeted treatment modalities. Robustly designed clinical trials have successfully integrated molecular epidemiology and the precision approach with population-based evidence-derived treatment approaches. Precision approaches are, nonetheless, imperfect tools and failure is frequently observed. Molecular information and the presence of an actionable target do 
not always translate to effective targeting of a driver mutation. Significant genetic heterogeneity is a major obstacle for population-based approaches, and identification of a target, without the knowledge of intertwined confounding factors, is not sufficient to formulate an efficacious treatment approach accordingly. Moreover, developing resistance is the main reason for treatment failure, and there are no effective tools to predict or prevent it.

The personalized approach can conceptually overcome many of these inadequacies by identification, analysis, and ex vivo simulation of the treatment approach. While personalized technologies are evolving and are not widely adopted in clinical practice, they have enormous potential to fill the gaps of conventional and modern precision approaches. They also facilitate drug discovery and development of novel therapeutic modalities. Ongoing research is focused on optimizing and validating these technologies, which can revolutionize our management of advanced cancers. We will see groundbreaking changes in the design of future clinical trials by integrating personalized treatment approaches. It is anticipated that personalized treatments will eventually improve the therapeutic efficacy and outcomes and decrease treatment toxicity and financial burden by avoiding futile toxic and expensive treatments. That being said, personalized approaches have a long way to go to be integrated into clinical practice and are not quite ready for prime time, and thus, they represent an exciting avenue for cancer research with a meaningful impact on outcomes.

Funding: This research received no external funding.

Conflicts of Interest: The authors declare no conflict of interest.

\section{References}

1. Kuipers, E.J.; Grady, W.M.; Lieberman, D.; Seufferlein, T.; Sung, J.J.; Boelens, P.G.; Van De Velde, C.J.H.; Watanabe, T. Colorectal cancer. Nat. Rev. Dis. Prim. 2015, 1, 15065. [CrossRef] [PubMed]

2. Rawla, P.; Sunkara, T.; Barsouk, A. Epidemiology of colorectal cancer: Incidence, mortality, survival, and risk factors. Gastroenterol. Rev. 2019, 14, 89-103. [CrossRef] [PubMed]

3. Bailey, C.E.; Hu, C.-Y.; You, Y.N.; Bednarski, B.K.; Rodriguez-Bigas, M.A.; Skibber, J.M.; Cantor, S.B.; Chang, G.J. Increasing Disparities in the Age-Related Incidences of Colon and Rectal Cancers in the United States, 1975-2010. JAMA Surg. 2015, 150, 17-22. [CrossRef] [PubMed]

4. Benson, A.B.; Venook, A.P.; Al-Hawary, M.M.; Cederquist, L.; Chen, Y.-J.; Ciombor, K.K.; Cohen, S.A.; Cooper, H.S.; Deming, D.; Engstrom, P.F.; et al. NCCN Guidelines Insights: Colon Cancer, Version 2.2018. J. Natl. Compr. Cancer Netw. 2018, 16, 359-369. [CrossRef]

5. Lin, J.S.; Piper, M.A.; Perdue, L.A.; Rutter, C.M.; Webber, E.M.; O'Connor, E.; Smith, N.; Whitlock, E.P. Screening for Colorectal Cancer. JAMA 2016, 315, 2576-2594. [CrossRef]

6. Jones, R.M.; Devers, K.J.; Kuzel, A.J.; Woolf, S.H. Patient-Reported Barriers to Colorectal Cancer Screening. Am. J. Prev. Med. 2010, 38, 508-516. [CrossRef]

7. Klabunde, C.N.; Vernon, S.W.; Nadel, M.R.; Breen, N.; Seeff, L.C.; Brown, M.L. Barriers to Colorectal Cancer Screening. Med. Care 2005, 43, 939-944. [CrossRef]

8. Perisetti, A.; Khan, H.; E George, N.; Yendala, R.; Rafiq, A.; Blakely, S.; Rasmussen, D.; Villalpando, N.; Goyal, H. Colorectal cancer screening use among insured adults: Is out-of-pocket cost a barrier to routine screening? World J. Gastrointest. Pharmacol. Ther. 2018, 9, 31-38. [CrossRef]

9. Brenner, H.; Kloor, M.; Pox, C.P. Colorectal cancer. Lancet 2014, 383, 1490-1502. [CrossRef]

10. Nakanishi, Y.; Diaz-Meco, M.T.; Moscat, J. Serrated Colorectal Cancer: The Road Less Travelled? Trends Cancer 2019, 5, 742-754. [CrossRef]

11. Montazeri, Z.; Li, X.; Nyiraneza, C.; Ma, X.; Timofeeva, M.; Svinti, V.; Meng, X.; He, Y.; Bo, Y.; Morgan, S.; et al. Systematic meta-analyses, field synopsis and global assessment of the evidence of genetic association studies in colorectal cancer. Gut 2019, 69, 1460-1471. [CrossRef] [PubMed]

12. Smith James, R. An Overview of the NIH Precision Medicine Initiative. Available online: https://www.nimhd. nih.gov/about/legislative-info/clips/pmi.html (accessed on 25 October 2020). 
13. Price, T.; Tang, M.; Gibbs, P.; Haller, D.G.; Peeters, M.; Arnold, D.; Chau, I.; Roy, A.; Tebbutt, N.; Pavlakis, N.; et al. Targeted therapy for metastatic colorectal cancer. Expert Rev. Anticancer. Ther. 2018, 18, 991-1006. [CrossRef] [PubMed]

14. Martini, G.; Troiani, T.; Cardone, C.; Vitiello, P.; Sforza, V.; Ciardiello, D.; Napolitano, S.; Della Corte, C.M.; Morgillo, F.; Raucci, A.; et al. Present and future of metastatic colorectal cancer treatment: A review of new candidate targets. World J. Gastroenterol. 2017, 23, 4675-4688. [CrossRef] [PubMed]

15. Antonacopoulou, A.G.; Tsamandas, A.C.; Petsas, T.; Liava, A.; Scopa, C.D.; Papavassiliou, A.G.; Kalofonos, H.P. EGFR, HER-2 and COX-2 levels in colorectal cancer. Histopathology 2008, 53, 698-706. [CrossRef] [PubMed]

16. McKay, J.A.; Murray, L.J.; Curran, S.; Ross, V.G.; Clark, C.; I Murray, G.; Cassidy, J.; McLeod, H.L. Evaluation of the epidermal growth factor receptor (EGFR) in colorectal tumours and lymph node metastases. Eur. J. Cancer 2002, 38, 2258-2264. [CrossRef]

17. Spano, J.-P.; Lagorce, C.; Atlan, D.; Milano, G.; Domont, J.; Benamouzig, R.; Attar, A.; Benichou, J.; Martin, A.; Morere, J.-F.; et al. Impact of EGFR expression on colorectal cancer patient prognosis and survival. Ann. Oncol. 2005, 16, 102-108. [CrossRef] [PubMed]

18. Yen, L.-C.; Uen, Y.-H.; Wu, D.-C.; Lu, C.-Y.; Yu, F.-J.; Wu, I.-C.; Lin, S.-R.; Wang, J.-Y. Activating KRAS Mutations and Overexpression of Epidermal Growth Factor Receptor as Independent Predictors in Metastatic Colorectal Cancer Patients Treated With Cetuximab. Ann. Surg. 2010, 251, 254-260. [CrossRef]

19. Allegra, C.J.; Rumble, R.B.; Hamilton, S.R.; Mangu, P.B.; Roach, N.; Hantel, A.; Schilsky, R.L. Extended RAS Gene Mutation Testing in Metastatic Colorectal Carcinoma to Predict Response to Anti-Epidermal Growth Factor Receptor Monoclonal Antibody Therapy: American Society of Clinical Oncology Provisional Clinical Opinion Update 2015. J. Clin. Oncol. 2016, 34, 179-185. [CrossRef]

20. Sepulveda, A.R.; Hamilton, S.R.; Allegra, C.J.; Grody, W.; Cushman-Vokoun, A.M.; Funkhouser, W.K.; Kopetz, S.E.; Lieu, C.; Lindor, N.M.; Minsky, B.D.; et al. Molecular Biomarkers for the Evaluation of Colorectal Cancer: Guideline From the American Society for Clinical Pathology, College of American Pathologists, Association for Molecular Pathology, and the American Society of Clinical Oncology. J. Clin. Oncol. 2017, 35, 1453-1486. [CrossRef]

21. Al-Shamsi, H.O.; Alhazzani, W.; Wolff, R.A. Extended RAS testing in metastatic colorectal cancer-Refining the predictive molecular biomarkers. J. Gastrointest. Oncol. 2015, 6, 314-321.

22. Rachiglio, A.M.; Lambiase, M.; Fenizia, F.; Roma, C.; Cardone, C.; Iannaccone, A.; De Luca, A.; Carotenuto, M.; Frezzetti, D.; Martinelli, E.; et al. Genomic Profiling of KRAS/NRAS/BRAF/PIK3CA Wild-Type Metastatic Colorectal Cancer Patients Reveals Novel Mutations in Genes Potentially Associated with Resistance to Anti-EGFR Agents. Cancers 2019, 11, 859. [CrossRef] [PubMed]

23. Prewett, M.; Hooper, A.T.; Bassi, R.; Ellis, L.M.; Waksal, H.W.; Hicklin, D.J. Enhanced antitumor activity of anti-epidermal growth factor receptor monoclonal antibody IMC-C225 in combination with irinotecan (CPT-11) against human colorectal tumor xenografts. Clin. Cancer Res. 2002, 8, 994-1003. [PubMed]

24. E Van Cutsem, E.; Lenz, H.-J.; Köhne, C.-H.; Heinemann, V.; Tejpar, S.; Melezínek, I.; Beier, F.; Stroh, C.; Rougier, P.; Van Krieken, J.H.; et al. Fluorouracil, Leucovorin, and Irinotecan Plus Cetuximab Treatment and RAS Mutations in Colorectal Cancer. J. Clin. Oncol. 2015, 33, 692-700. [CrossRef] [PubMed]

25. Sobrero, A.F.; Maurel, J.; Fehrenbacher, L.; Scheithauer, W.; Abubakr, Y.A.; Lutz, M.P.; Vega-Villegas, M.E.; Eng, C.; Steinhauer, E.U.; Prausova, J.; et al. EPIC: Phase III Trial of Cetuximab Plus Irinotecan After Fluoropyrimidine and Oxaliplatin Failure in Patients With Metastatic Colorectal Cancer. J. Clin. Oncol. 2008, 26, 2311-2319. [CrossRef] [PubMed]

26. Cunningham, D.; Humblet, Y.; Siena, S.; Khayat, D.; Bleiberg, H.; Santoro, A.; Bets, D.; Mueser, M.; Harstrick, A.; Verslype, C.; et al. Cetuximab Monotherapy and Cetuximab plus Irinotecan in Irinotecan-Refractory Metastatic Colorectal Cancer. N. Engl. J. Med. 2004, 351, 337-345. [CrossRef] [PubMed]

27. Douillard, J.-Y.; Oliner, K.S.; Siena, S.; Tabernero, J.; Burkes, R.; Barugel, M.; Humblet, Y.; Bodoky, G.; Cunningham, D.; Jassem, J.; et al. Panitumumab-FOLFOX4 Treatment and RAS Mutations in Colorectal Cancer. N. Engl. J. Med. 2013, 369, 1023-1034. [CrossRef] [PubMed]

28. Douillard, J.-Y.; Siena, S.; Cassidy, J.; Tabernero, J.; Burkes, R.; Barugel, M.; Humblet, Y.; Bodoky, G.; Cunningham, D.; Jassem, J.; et al. Final results from PRIME: Randomized phase III study of panitumumab with FOLFOX4 for first-line treatment of metastatic colorectal cancer. Ann. Oncol. 2014, 25, 1346-1355. [CrossRef] 
29. Bokemeyer, C.; Bondarenko, I.; Hartmann, J.T.; De Braud, F.; Schuch, G.; Zubel, A.; Celik, I.; Schlichting, M.; Koralewski, P. Efficacy according to biomarker status of cetuximab plus FOLFOX-4 as first-line treatment for metastatic colorectal cancer: The OPUS study. Ann. Oncol. 2011, 22, 1535-1546. [CrossRef]

30. Qin, S.; Li, J.; Wang, L.; Xu, J.; Cheng, Y.; Bai, Y.; Li, W.; Xu, N.; Lin, L.-Z.; Wu, Q.; et al. Efficacy and Tolerability of First-Line Cetuximab Plus Leucovorin, Fluorouracil, and Oxaliplatin (FOLFOX-4) Versus FOLFOX-4 in Patients With RAS Wild-Type Metastatic Colorectal Cancer: The Open-Label, Randomized, Phase III TAILOR Trial. J. Clin. Oncol. 2018, 36, 3031-3039. [CrossRef]

31. Amado, R.G.; Wolf, M.; Peeters, M.; E Van Cutsem, E.; Siena, S.; Freeman, D.J.; Juan, T.; Sikorski, R.; Suggs, S.; Radinsky, R.; et al. Wild-TypeKRASIs Required for Panitumumab Efficacy in Patients With Metastatic Colorectal Cancer. J. Clin. Oncol. 2008, 26, 1626-1634. [CrossRef]

32. Ciardiello, F.; Normanno, N.; Martinelli, E.; Troiani, T.; Pisconti, S.; Cardone, C.; Nappi, A.; Bordonaro, A.R.; Rachiglio, M.; Lambiase, M.; et al. Cetuximab continuation after first progression in metastatic colorectal cancer (CAPRI-GOIM): A randomized phase II trial of FOLFOX plus cetuximab versus FOLFOX. Ann. Oncol. 2016, 27, 1055-1061. [CrossRef] [PubMed]

33. Sandhu, J.; Lavingia, V.; Fakih, M. Systemic treatment for metastatic colorectal cancer in the era of precision medicine. J. Surg. Oncol. 2019, 119, 564-582. [CrossRef] [PubMed]

34. Primrose, J.N.; Falk, S.; Finch-Jones, M.; Valle, J.; O’Reilly, D.; Siriwardena, A.; Hornbuckle, J.; Peterson, M.; Rees, M.; Iveson, T.; et al. Systemic chemotherapy with or without cetuximab in patients with resectable colorectal liver metastasis: The New EPOC randomised controlled trial. Lancet Oncol. 2014, 15, 601-611. [CrossRef]

35. Parseghian, C.M.; Napolitano, S.; Loree, J.M.; Kopetz, S. Mechanisms of Innate and Acquired Resistance to Anti-EGFR Therapy: A Review of Current Knowledge with a Focus on Rechallenge Therapies. Clin. Cancer Res. 2019, 25, 6899-6908. [CrossRef]

36. Misale, S.; Di Nicolantonio, F.; Sartore-Bianchi, A.; Siena, S.; Bardelli, A. Resistance to Anti-EGFR Therapy in Colorectal Cancer: From Heterogeneity to Convergent Evolution. Cancer Discov. 2014, 4, 1269-1280. [CrossRef]

37. Xu, J.; Zeng, L.-F.; Shen, W.; Turchi, J.J.; Zhang, Z.-Y. Targeting SHP2 for EGFR inhibitor resistant non-small cell lung carcinoma. Biochem. Biophys. Res. Commun. 2013, 439, 586-590. [CrossRef]

38. Park, S.; Hwang, C.Y.; Cho, S.; Lee, D.; Gong, J.; Lee, S.; Nam, S.; Cho, K.-H. Systems analysis identifies potential target genes to overcome cetuximab resistance in colorectal cancer cells. FEBS J. 2019, 286, 1305-1318. [CrossRef]

39. Hong, D.S.; Fakih, M.G.; Strickler, J.H.; Desai, J.; Durm, G.A.; Shapiro, G.I.; Falchook, G.S.; Price, T.J.; Sacher, A.; Denlinger, C.S.; et al. KRASG12C Inhibition with Sotorasib in Advanced Solid Tumors. N. Engl. J. Med. 2020, 383, 1207-1217. [CrossRef]

40. Del Re, M.; Crucitta, S.; Gianfilippo, G.; Passaro, A.; Petrini, I.; Restante, G.; Michelucci, A.; Fogli, S.; De Marinis, F.; Porta, C.; et al. Understanding the Mechanisms of Resistance in EGFR-Positive NSCLC: From Tissue to Liquid Biopsy to Guide Treatment Strategy. Int. J. Mol. Sci. 2019, 20, 3951. [CrossRef]

41. Gale, D.; Lawson, A.R.J.; Howarth, K.; Madi, M.; Durham, B.; Smalley, S.; Calaway, J.; Blais, S.; Jones, G.; Clark, J.; et al. Development of a highly sensitive liquid biopsy platform to detect clinically-relevant cancer mutations at low allele fractions in cell-free DNA. PLoS ONE 2018, 13, e0194630. [CrossRef]

42. Venook, A.P.; Niedzwiecki, N.; Lenz, H.-J.; Innocenti, F.; Fruth, B.; Meyerhardt, J.A.; Schrag, D.; Greene, C.; O'Neil, B.H.; Atkins, J.N.; et al. Effect of First-Line Chemotherapy Combined With Cetuximab or Bevacizumab on Overall Survival in Patients With KRAS Wild-Type Advanced or Metastatic Colorectal Cancer: A Randomized Clinical Trial. JAMA 2017, 317, 2392-2401. [CrossRef] [PubMed]

43. Venook, A.P.; Niedzwiecki, D.; Innocenti, F.; Fruth, B.; Greene, C.; O’Neil, B.H.; Shaw, J.E.; Atkins, J.N.; Horvath, L.E.; Polite, B.N.; et al. Impact of primary $\left(1^{\circ}\right)$ tumor location on overall survival (OS) and progression-free survival (PFS) in patients (pts) with metastatic colorectal cancer (mCRC): Analysis of CALGB/SWOG 80405 (Alliance). J. Clin. Oncol. 2016, 34, 3504. [CrossRef]

44. Boland, C.R.; Goel, A. Microsatellite Instability in Colorectal Cancer. Gastroenterology 2010, 138, 2073-2087. [CrossRef] [PubMed]

45. You, A.J.; You, C.Y. Biomarkers in Colorectal Cancer. Anticancer Res. 2016, 36, 1093-1102.

46. Punt, C.J.A.; Koopman, M.; Vermeulen, L. From tumour heterogeneity to advances in precision treatment of colorectal cancer. Nat. Rev. Clin. Oncol. 2017, 14, 235-246. [CrossRef] [PubMed] 
47. Quasar Collaborative Group. Adjuvant chemotherapy versus observation in patients with colorectal cancer: A randomised study. Lancet 2007, 370, 2020-2029. [CrossRef]

48. Hutchins, G.; Southward, K.; Handley, K.; Magill, L.; Beaumont, C.; Stahlschmidt, J.; Richman, S.; Chambers, P.; Seymour, M.; Kerr, D.; et al. Value of Mismatch Repair, KRAS, and BRAF Mutations in Predicting Recurrence and Benefits From Chemotherapy in Colorectal Cancer. J. Clin. Oncol. 2011, 29, 1261-1270. [CrossRef]

49. Gavin, P.G.; Colangelo, L.H.; Fumagalli, D.; Tanaka, N.; Remillard, M.Y.; Yothers, G.; Kim, C.; Taniyama, Y.; Kim, S.I.; Choi, H.J.; et al. Mutation Profiling and Microsatellite Instability in Stage II and III Colon Cancer: An Assessment of Their Prognostic and Oxaliplatin Predictive Value. Clin. Cancer Res. 2012, 18, 6531-6541. [CrossRef]

50. Sargent, D.J.; Marsoni, S.; Monges, G.; Thibodeau, S.N.; Labianca, R.; Hamilton, S.R.; French, A.J.; Kabat, B.; Foster, N.R.; Torri, V.; et al. Defective Mismatch Repair As a Predictive Marker for Lack of Efficacy of Fluorouracil-Based Adjuvant Therapy in Colon Cancer. J. Clin. Oncol. 2010, 28, 3219-3226. [CrossRef]

51. Pogue-Geile, K.; Yothers, G.; Taniyama, Y.; Tanaka, N.; Gavin, P.; Colangelo, L.; Blackmon, N.; Lipchik, C.; Kim, S.R.; Sharif, S.; et al. Defective Mismatch Repair and Benefit from Bevacizumab for Colon Cancer: Findings from NSABP C-08. J. Natl. Cancer Inst. 2013, 105, 989-992. [CrossRef]

52. Llosa, N.J.; Cruise, M.; Tam, A.; Wicks, E.C.; Hechenbleikner, E.M.; Taube, J.M.; Blosser, R.L.; Fan, H.; Wang, H.; Luber, B.S.; et al. The Vigorous Immune Microenvironment of Microsatellite Instable Colon Cancer Is Balanced by Multiple Counter-Inhibitory Checkpoints. Cancer Discov. 2015, 5, 43-51. [CrossRef] [PubMed]

53. Wu, X.; Gu, Z.; Chen, Y.; Chen, B.; Chen, W.; Weng, L.; Liu, X. Application of PD-1 Blockade in Cancer Immunotherapy. Comput. Struct. Biotechnol. J. 2019, 17, 661-674. [CrossRef] [PubMed]

54. Overman, M.J.; McDermott, R.; Leach, J.L.; Lonardi, S.; Lenz, H.-J.; Morse, M.A.; Desai, J.; Hill, A.; Axelson, M.; Moss, R.A.; et al. Nivolumab in patients with metastatic DNA mismatch repair-deficient or microsatellite instability-high colorectal cancer (CheckMate 142): An open-label, multicentre, phase 2 study. Lancet Oncol. 2017, 18, 1182-1191. [CrossRef]

55. Le, D.T.; Uram, J.N.; Wang, H.; Bartlett, B.R.; Kemberling, H.; Eyring, A.D.; Skora, A.D.; Luber, B.S.; Azad, N.S.; Laheru, D.; et al. PD-1 Blockade in Tumors with Mismatch-Repair Deficiency. N. Engl. J. Med. 2015, 372, 2509-2520. [CrossRef] [PubMed]

56. Le, D.T.; Kim, T.W.; Van Cutsem, E.; Geva, R.; Jäger, D.; Hara, H.; Burge, M.; O’Neil, B.; Kavan, P.; Yoshino, T.; et al. Phase II Open-Label Study of Pembrolizumab in Treatment-Refractory, Microsatellite Instability-High/Mismatch Repair-Deficient Metastatic Colorectal Cancer: KEYNOTE-164. J. Clin. Oncol. 2020, 38, 11-19. [CrossRef]

57. Fumet, J.-D.; Isambert, N.; Hervieu, A.; Zanetta, S.; Guion, J.-F.; Hennequin, A.; Rederstorff, E.; Bertaut, A.; Ghiringhelli, F. Phase Ib/II trial evaluating the safety, tolerability and immunological activity of durvalumab (MEDI4736) (anti-PD-L1) plus tremelimumab (anti-CTLA-4) combined with FOLFOX in patients with metastatic colorectal cancer. ESMO Open 2018, 3, e000375. [CrossRef]

58. Andre, T.; Shiu, K.-K.; Kim, T.W.; Jensen, B.V.; Jensen, L.H.; Punt, C.J.A.; Smith, D.M.; Garcia-Carbonero, R.; Benavides, M.; Gibbs, P.; et al. Pembrolizumab versus chemotherapy for microsatellite instability-high/mismatch repair deficient metastatic colorectal cancer: The phase 3 KEYNOTE-177 Study. J. Clin. Oncol. 2020, 38, LBA4. [CrossRef]

59. US Food and Drug Administration. FDA Approves Pembrolizumab for First-line Treatment of MSI-H/dMMR Colorectal Cancer. Available online: https:/www.fda.gov/drugs/drug-approvals-and-databases/fdaapproves-pembrolizumab-first-line-treatment-msi-hdmmr-colorectal-cancer (accessed on 25 October 2020).

60. Federation Francophone de Cancerologie Digestive. Pembrolizumab in Combination with Xelox Bevacizumab in Patients With Microsatellite Stable Mestatic Colorectal Cancer and a High Immune Infiltrate: A Proof of Concept Study. Available online: https://clinicaltrials.gov/ct2/show/NCT04262687 (accessed on 18 September 2020).

61. Fondazione IRCCS Istituto Nazionale dei Tumori. NIVOLUMAB Plus IPILIMUMAB and TEMOZOLOMIDE in Combination in Microsatellite Stable (MSS), MGMT Silenced Metastatic Colorectal Cancer (mCRC): The MAYA Study. Available online: https://clinicaltrials.gov/ct2/show/NCT03832621 (accessed on 18 September 2020).

62. Marmorino, F.; Boccaccino, A.; Germani, M.M.; Falcone, A.; Cremolini, C. Immune Checkpoint Inhibitors in pMMR Metastatic Colorectal Cancer: A Tough Challenge. Cancers 2020, 12, 2317. [CrossRef] 
63. Ghiringhelli, F.; Fumet, J.-D. Is There a Place for Immunotherapy for Metastatic Microsatellite Stable Colorectal Cancer? Front. Immunol. 2019, 10, 1816. [CrossRef]

64. Bond, C.E.; Whitehall, V.L.J. How theBRAFV600E Mutation Defines a Distinct Subgroup of Colorectal Cancer: Molecular and Clinical Implications. Gastroenterol. Res. Pract. 2018, 2018, 1-14. [CrossRef]

65. Davies, N.; Bignell, G.R.; Cox, C.; Stephens, P.; Edkins, S.; Clegg, S.; Teague, J.W.; Woffendin, H.; Garnett, M.J.; Bottomley, W.; et al. Mutations of the BRAF gene in human cancer. Nature 2002, 417, 949-954. [CrossRef] [PubMed]

66. Di Nicolantonio, F.; Martini, M.; Molinari, F.; Sartore-Bianchi, A.; Arena, S.; Saletti, P.; De Dosso, S.; Mazzucchelli, L.; Frattini, M.; Siena, S.; et al. Wild-Type BRAF Is Required for Response to Panitumumab or Cetuximab in Metastatic Colorectal Cancer. J. Clin. Oncol. 2008, 26, 5705-5712. [CrossRef] [PubMed]

67. Mao, C.; Liao, R.-Y.; Qiu, L.-X.; Wang, X.-W.; Ding, H.; Chen, Q. BRAF V600E mutation and resistance to anti-EGFR monoclonal antibodies in patients with metastatic colorectal cancer: A meta-analysis. Mol. Biol. Rep. 2010, 38, 2219-2223. [CrossRef] [PubMed]

68. Pietrantonio, F.; Petrelli, F.; Coinu, A.; Di Bartolomeo, M.; Borgonovo, K.; Maggi, C.; Cabiddu, M.; Iacovelli, R.; Bossi, I.; Lonati, V.; et al. Predictive role of BRAF mutations in patients with advanced colorectal cancer receiving cetuximab and panitumumab: A meta-analysis. Eur. J. Cancer 2015, 51, 587-594. [CrossRef]

69. Yaeger, R.; Cercek, A.; O’Reilly, E.M.; Reidy, D.L.; Kemeny, N.; Wolinsky, T.; Capanu, M.; Gollub, M.J.; Rosen, N.; Berger, M.F.; et al. Pilot Trial of Combined BRAF and EGFR Inhibition in BRAF-Mutant Metastatic Colorectal Cancer Patients. Clin. Cancer Res. 2015, 21, 1313-1320. [CrossRef]

70. Hong, D.S.; Morris, V.K.; El Osta, B.; Sorokin, A.V.; Janku, F.; Funda, M.-B.; Overman, M.J.; Piha-Paul, S.; Subbiah, V.; Kee, B.; et al. Phase IB Study of Vemurafenib in Combination with Irinotecan and Cetuximab in Patients with Metastatic Colorectal Cancer with BRAFV600E Mutation. Cancer Discov. 2016, 6, 1352-1365. [CrossRef]

71. Southwest Oncology Group. S1406 Phase II Study of Irinotecan and Cetuximab With or Without Vemurafenib in BRAF Mutant Metastatic Colorectal Cancer. Available online: https:/clinicaltrials.gov/ct2/ show/NCT02164916 (accessed on 5 January 2020).

72. Kopetz, S.; Grothey, A.; Yaeger, R.; Van Cutsem, E.; Desai, J.; Yoshino, T.; Wasan, H.; Ciardiello, F.; Loupakis, F.; Hong, Y.S.; et al. Encorafenib, Binimetinib, and Cetuximab in BRAF V600E-Mutated Colorectal Cancer. N. Engl. J. Med. 2019, 381, 1632-1643. [CrossRef]

73. Kopetz, S.; Grothey, A.; Van Cutsem, E.; Yaeger, R.; Wasan, H.S.; Yoshino, T.; Desai, J.; Ciardiello, F.; Loupakis, F.; Hong, Y.S.; et al. Encorafenib plus cetuximab with or without binimetinib for BRAF V600E metastatic colorectal cancer: Updated survival results from a randomized, three-arm, phase III study versus choice of either irinotecan or FOLFIRI plus cetuximab (BEACON CRC). J. Clin. Oncol. 2020, 38, 4001. [CrossRef]

74. Fujisaki, J.; Shinozaki, E.; Wakatsuki, T.; Suenaga, M.; Ichimura, T.; Ogura, M.; Takahari, D.; Ooki, A.; Suzuki, T.; Ota, Y.; et al. Non-V600E BRAF mutations and EGFR signaling pathway in colorectal cancer. Int. J. Cancer 2019, 145, 2488-2495. [CrossRef]

75. Shinozaki, E.; Yoshino, T.; Yamazaki, K.; Muro, K.; Yamaguchi, K.; Nishina, T.; Takayuki, Y.; Shitara, K.; Bando, H.; Mimaki, S.; et al. Clinical significance of BRAF non-V600E mutations on the therapeutic effects of anti-EGFR monoclonal antibody treatment in patients with pretreated metastatic colorectal cancer: The Biomarker Research for anti-EGFR monoclonal Antibodies by Comprehensive Cancer genomics (BREAC) study. Br. J. Cancer 2017, 117, 1450-1458. [CrossRef]

76. Sun, W. Angiogenesis in metastatic colorectal cancer and the benefits of targeted therapy. J. Hematol. Oncol. 2012, 5, 63. [CrossRef]

77. Hurwitz, H.I.; Fehrenbacher, L.; Novotny, W.; Cartwright, T.; Hainsworth, J.; Heim, W.; Berlin, J.; Baron, A.; Griffing, S.; Holmgren, E.; et al. Bevacizumab plus Irinotecan, Fluorouracil, and Leucovorin for Metastatic Colorectal Cancer. N. Engl. J. Med. 2004, 350, 2335-2342. [CrossRef]

78. Guan, Z.-Z.; Xu, J.-M.; Luo, R.-C.; Feng, F.-Y.; Wang, L.-W.; Shen, L.; Yu, S.-Y.; Ba, Y.; Liang, J.; Wang, D.; et al. Efficacy and safety of bevacizumab plus chemotherapy in Chinese patients with metastatic colorectal cancer: A randomized phase III ARTIST trial. Chin. J. Cancer 2011, 30, 682-689. [CrossRef]

79. Loupakis, F.; Cremolini, C.; Masi, G.; Lonardi, S.; Zagonel, V.; Salvatore, L.; Cortesi, E.; Tomasello, G.; Ronzoni, M.; Spadi, R.; et al. Initial Therapy with FOLFOXIRI and Bevacizumab for Metastatic Colorectal Cancer. N. Engl. J. Med. 2014, 371, 1609-1618. [CrossRef] [PubMed] 
80. Cremolini, C.; Loupakis, F.; Antoniotti, C.; Lonardi, S.; Masi, G.; Salvatore, L.; Cortesi, E.; Tomasello, G.; Spadi, R.; Zaniboni, A.; et al. Early tumor shrinkage and depth of response predict long-term outcome in metastatic colorectal cancer patients treated with first-line chemotherapy plus bevacizumab: Results from phase III TRIBE trial by the Gruppo Oncologico del Nord Ovest. Ann. Oncol. 2015, 26, 1188-1194. [CrossRef] [PubMed]

81. Kozloff, M.; Yood, M.U.; Berlin, J.; Flynn, P.J.; Kabbinavar, F.F.; Purdie, D.M.; Ashby, M.A.; Dong, W.; Sugrue, M.M.; Grothey, A.; et al. Clinical Outcomes Associated with Bevacizumab-Containing Treatment of Metastatic Colorectal Cancer: The BRiTE Observational Cohort Study. Oncology 2009, 14, 862-870. [CrossRef] [PubMed]

82. Giantonio, B.J.; Catalano, P.J.; Meropol, N.J.; O’Dwyer, P.J.; Mitchell, E.P.; Alberts, S.R.; Schwartz, M.A.; Benson, A.B. Bevacizumab in Combination With Oxaliplatin, Fluorouracil, and Leucovorin (FOLFOX4) for Previously Treated Metastatic Colorectal Cancer: Results From the Eastern Cooperative Oncology Group Study E3200. J. Clin. Oncol. 2007, 25, 1539-1544. [CrossRef] [PubMed]

83. Saltz, L.B.; Clarke, S.; Díaz-Rubio, E.; Scheithauer, W.; Figer, A.; Wong, R.; Koski, S.; Lichinitser, M.; Yang, T.-S.; Rivera, F.; et al. Bevacizumab in Combination With Oxaliplatin-Based Chemotherapy As First-Line Therapy in Metastatic Colorectal Cancer: A Randomized Phase III Study. J. Clin. Oncol. 2008, 26, 2013-2019. [CrossRef]

84. Van Cutsem, E.; Rivera, F.D.L.; Berry, S.M.; Kretzschmar, A.; Michael, M.; DiBartolomeo, M.; Mazier, M.-A.; Canon, J.-L.; Georgoulias, V.; Peeters, M.; et al. Safety and efficacy of first-line bevacizumab with FOLFOX, XELOX, FOLFIRI and fluoropyrimidines in metastatic colorectal cancer: The BEAT study. Ann. Oncol. 2009, 20, 1842-1847. [CrossRef]

85. Nishina, T.; Takano, Y.; Denda, T.; Yasui, H.; Takeda, K.; Ura, T.; Esaki, T.; Okuyama, Y.; Kondo, K.; Takahashi, Y.; et al. A Phase II Clinical Study of mFOLFOX6 Plus Bevacizumab as First-line Therapy for Japanese Advanced/Recurrent Colorectal Cancer Patients. Jpn. J. Clin. Oncol. 2013, 43, 1080-1086. [CrossRef]

86. Van Cutsem, E.; Tabernero, J.; Lakomy, R.; Prenen, H.; Prausová, J.; Macarulla, T.; Ruff, P.; Van Hazel, G.A.; Moiseyenko, V.; Ferry, D.; et al. Addition of Aflibercept to Fluorouracil, Leucovorin, and Irinotecan Improves Survival in a Phase III Randomized Trial in Patients With Metastatic Colorectal Cancer Previously Treated With an Oxaliplatin-Based Regimen. J. Clin. Oncol. 2012, 30, 3499-3506. [CrossRef] [PubMed]

87. Tabernero, J.; Yoshino, T.; Cohn, A.L.; Obermannova, R.; Bodoky, G.G.; Garcia-Carbonero, R.; Ciuleanu, T.-E.; Portnoy, D.C.; Van Cutsem, E.; Grothey, A.; et al. Ramucirumab versus placebo in combination with second-line FOLFIRI in patients with metastatic colorectal carcinoma that progressed during or after first-line therapy with bevacizumab, oxaliplatin, and a fluoropyrimidine (RAISE): A randomised, double-blind, multicentre, phase 3 study. Lancet Oncol. 2015, 16, 499-508. [CrossRef] [PubMed]

88. Boku, N.; Yamamoto, S. Selection of Second-line Anti-angiogenic Agents After Failure of Bevacizumab-containing First-line Chemotherapy in Metastatic Colorectal Cancer. Clin. Color Cancer 2018, 17, 251-254. [CrossRef] [PubMed]

89. Grothey, A.; Van Cutsem, E.; Sobrero, A.; Siena, S.; Falcone, A.; Ychou, M.; Humblet, Y.; Bouché, O.; Mineur, L.; Barone, C.A.; et al. Regorafenib monotherapy for previously treated metastatic colorectal cancer (CORRECT): An international, multicentre, randomised, placebo-controlled, phase 3 trial. Lancet 2013, 381, 303-312. [CrossRef]

90. Eng, C.; Kim, T.W.; Bendell, J.; Argilés, G.; Tebbutt, N.C.; Di Bartolomeo, M.; Falcone, A.; Fakih, M.; Kozloff, M.; Segal, N.H.; et al. Atezolizumab with or without cobimetinib versus regorafenib in previously treated metastatic colorectal cancer (IMblaze370): A multicentre, open-label, phase 3, randomised, controlled trial. Lancet Oncol. 2019, 20, 849-861. [CrossRef]

91. Jayson, G.C.; Zhou, C.; Backen, A.; Horsley, L.; Marti-Marti, K.; Shaw, D.; Mescallado, N.; Clamp, A.; Saunders, M.P.; Valle, J.W.; et al. Plasma Tie2 is a tumor vascular response biomarker for VEGF inhibitors in metastatic colorectal cancer. Nat. Commun. 2018, 9, 1-14. [CrossRef]

92. Heinemann, V.; Von Weikersthal, L.F.; Decker, T.; Kiani, A.; Vehling-Kaiser, U.; Al-Batran, S.-E.; Heintges, T.; Lerchenmüller, C.; Kahl, C.; Seipelt, G.; et al. FOLFIRI plus cetuximab versus FOLFIRI plus bevacizumab as first-line treatment for patients with metastatic colorectal cancer (FIRE-3): A randomised, open-label, phase 3 trial. Lancet Oncol. 2014, 15, 1065-1075. [CrossRef]

93. Wu, S.-W.; Ma, C.-C.; Li, W.-H. Does overexpression of HER-2 correlate with clinicopathological characteristics and prognosis in colorectal cancer? Evidence from a meta-analysis. Diagn. Pathol. 2015, 10, 144. [CrossRef] 
94. Martin, V.; Landi, L.; Molinari, F.; Fountzilas, G.; Geva, R.; Riva, A.; Saletti, P.; De Dosso, S.; Spitale, A.; Tejpar, S.; et al. HER2 gene copy number status may influence clinical efficacy to anti-EGFR monoclonal antibodies in metastatic colorectal cancer patients. Br. J. Cancer 2013, 108, 668-675. [CrossRef]

95. Meric-Bernstam, F.; Hurwitz, H.; Raghav, K.P.S.; McWilliams, R.R.; Fakih, M.; VanderWalde, A.; Swanton, C.; Kurzrock, R.; Burris, H.; Sweeney, C.; et al. Pertuzumab plus trastuzumab for HER2-amplified metastatic colorectal cancer (MyPathway): An updated report from a multicentre, open-label, phase 2a, multiple basket study. Lancet Oncol. 2019, 20, 518-530. [CrossRef]

96. Sartore-Bianchi, A.; Trusolino, L.; Martino, C.; Bencardino, K.; Lonardi, S.; Bergamo, F.; Zagonel, V.; Leone, F.; Depetris, I.; Martinelli, E.; et al. Dual-targeted therapy with trastuzumab and lapatinib in treatment-refractory, KRAS codon 12/13 wild-type, HER2-positive metastatic colorectal cancer (HERACLES): A proof-of-concept, multicentre, open-label, phase 2 trial. Lancet Oncol. 2016, 17, 738-746. [CrossRef]

97. Sartore-Bianchi, A.; Martino, C.; Lonardi, S.; Fenocchio, E.; Amatu, A.; Ghezzi, S.; Zagonel, V.; Ciardiello, F.; Ardizzoni, A.; Tosi, F.; et al. Phase II study of pertuzumab and trastuzumab-emtansine (T-DM1) in patients with HER2-positive metastatic colorectal cancer: The HERACLES-B (HER2 Amplification for Colo-rectaL cancer Enhanced Stratification, cohort B) trial. Ann. Oncol. 2019, 30, v869-v870. [CrossRef]

98. Siena, S.; Bardelli, A.; Sartore-Bianchi, A.; Martino, C.; Siravegna, G.; Magri', A.; Leone, F.; Zagonel, V.; Lonardi, S.; Amatu, A.; et al. HER2 amplification as a 'molecular bait' for trastuzumab-emtansine (T-DM1) precision chemotherapy to overcome anti-HER2 resistance in HER2 positive metastatic colorectal cancer: The HERACLES-RESCUE trial. J. Clin. Oncol. 2016, 34, TPS774. [CrossRef]

99. Yoshino, T.; Siena, S.; Dalal, R.; Okuda, Y.; Yamamoto, E.; Grothey, A. A multicenter, multicohort, phase 2 study of trastuzumab deruxtecan (DS-8201a) in subjects with HER2-expressing metastatic colorectal cancer Trial in progress. Ann. Oncol. 2018, 29, v83. [CrossRef]

100. Karakas, B.; E Bachman, K.; Park, B.H. Mutation of the PIK3CA oncogene in human cancers. Br. J. Cancer 2006, 94, 455-459. [CrossRef] [PubMed]

101. De Roock, W.; Claes, B.; Bernasconi, D.; De Schutter, J.; Biesmans, B.; Fountzilas, G.; Kalogeras, K.T.; Kotoula, V.; Papamichael, D.; Laurent-Puig, P.; et al. Effects of KRAS, BRAF, NRAS, and PIK3CA mutations on the efficacy of cetuximab plus chemotherapy in chemotherapy-refractory metastatic colorectal cancer: A retrospective consortium analysis. Lancet Oncol. 2010, 11, 753-762. [CrossRef]

102. Ogino, S.; Nosho, K.; Kirkner, G.J.; Shima, K.; Irahara, N.; Kure, S.; Chan, A.T.; Engelman, J.A.; Kraft, P.; Cantley, L.C.; et al. PIK3CA Mutation Is Associated With Poor Prognosis Among Patients With Curatively Resected Colon Cancer. J. Clin. Oncol. 2009, 27, 1477-1484. [CrossRef]

103. Mao, C.; Yang, Z.Y.; Hu, X.F.; Chen, Q.; Tang, J.-L. PIK3CA exon 20 mutations as a potential biomarker for resistance to anti-EGFR monoclonal antibodies in KRAS wild-type metastatic colorectal cancer: A systematic review and meta-analysis. Ann. Oncol. 2012, 23, 1518-1525. [CrossRef]

104. Sartore-Bianchi, A.; Martini, M.; Molinari, F.; Veronese, S.; Nichelatti, M.; Artale, S.; Di Nicolantonio, F.; Saletti, P.; De Dosso, S.; Mazzucchelli, L.; et al. PIK3CA Mutations in Colorectal Cancer Are Associated with Clinical Resistance to EGFR-Targeted Monoclonal Antibodies. Cancer Res. 2009, 69, 1851-1857. [CrossRef]

105. Liao, X.; Lochhead, P.; Nishihara, R.; Morikawa, T.; Kuchiba, A.; Yamauchi, M.; Imamura, Y.; Qian, Z.R.; Baba, Y.; Shima, K.; et al. Aspirin Use, TumorPIK3CAMutation, and Colorectal-Cancer Survival. N. Engl. J. Med. 2012, 367, 1596-1606. [CrossRef]

106. Memorial Sloan Kettering Cancer Center. Clinical And Translational Study Of MK-2206 In Patients With Metastatic KRAS-Wild-Type, PIK3CA-Mutated, Colorectal Cancer. Available online: https://clinicaltrials. gov/ct2/show/results/NCT01186705 (accessed on 2 February 2020).

107. Hamid, O.; Hoffner, B.; Gasal, E.; Hong, J.; Carvajal, R.D. Oncolytic immunotherapy: Unlocking the potential of viruses to help target cancer. Cancer Immunol. Immunother. 2017, 66, 1249-1264. [CrossRef] [PubMed]

108. Andtbacka, R.H.; Kaufman, H.L.; Collichio, F.; Amatruda, T.; Senzer, N.; Chesney, J.; Delman, K.A.; Spitler, L.E.; Puzanov, I.; Agarwala, S.S.; et al. Talimogene Laherparepvec Improves Durable Response Rate in Patients With Advanced Melanoma. J. Clin. Oncol. 2015, 33, 2780-2788. [CrossRef] [PubMed]

109. Yang, H.; Peng, T.; Li, J.; Wang, Y.; Zhang, W.; Zhang, P.; Peng, S.; Du, T.; Li, Y.; Yan, Q.; et al. Treatment of colon cancer with oncolytic herpes simplex virus in preclinical models. Gene Ther. 2016, 23, 450-459. [CrossRef] [PubMed] 
110. Parakrama, R.; Chaudhary, I.; Coffey, M.C.; Goel, S.; Maitra, R. Immune response to reovirus (REO) in phase I study with chemotherapy in patients with KRAS mutant metastatic colorectal cancer (mCRC). J. Clin. Oncol. 2018, 36, 217. [CrossRef]

111. Ocean, A.J.; Bekaii-Saab, T.S.; Chaudhary, I.; Palmer, R.; Christos, P.J.; Mercado, A.; Florendo, E.O.; Rosales, V.A.; Ruggiero, J.T.; Popa, E.C.; et al. A multicenter phase I study of intravenous administration of reolysin in combination with irinotecan/fluorouracil/leucovorin (FOLFIRI) in patients (pts) with oxaliplatin-refractory/intolerant KRAS-mutant metastatic colorectal cancer (mCRC). J. Clin. Oncol. 2013, 31, 450. [CrossRef]

112. Turnstone Biologics, Corp. Study of TBio-6517, Given Intratumorally, Alone or in Combination with Pembrolizumab, in Solid Tumors. Available online: https:/clinicaltrials.gov/ct2/show/NCT04301011 (accessed on 20 September 2020).

113. Oncolytics Biotech. Study of REOLYSIN@in Combination With FOLFIRI and Bevacizumab in FOLFIRI Naive Patients With KRAS Mutant Metastatic Colorectal Cancer. Available online: https://clinicaltrials.gov/ ct2/show/NCT01274624 (accessed on 20 September 2020).

114. Jennerex Biotherapeutics. Recombinant Vaccinia Virus Administered Intravenously in Patients With Metastatic, Refractory Colorectal Carcinoma. Available online: https:/clinicaltrials.gov/ct2/show/ NCT01394939 (accessed on 20 September 2020).

115. National Cancer Institute (NCI). National Cancer Institute (NCI). A Phase I/II Study of Pexa-Vec Oncolytic Virus in Combination with Immune Checkpoint Inhibition in Refractory Colorectal Cancer. Available online: https://clinicaltrials.gov/ct2/show/NCT03206073 (accessed on 18 September 2020).

116. Lokon Pharma AB. Trial Investigating an Immunostimulatory Oncolytic Adenovirus for Cancer. Available online: https://clinicaltrials.gov/ct2/show/NCT03225989 (accessed on 20 September 2020).

117. Buijs, P.; Verhagen, J.H.; Van Eijck, C.; Hoogen, B.V.D. Oncolytic viruses: From bench to bedside with a focus on safety. Hum. Vaccines Immunother. 2015, 11, 1573-1584. [CrossRef]

118. Liu, T.-C.; Galanis, E.; Kirn, D.H. Clinical trial results with oncolytic virotherapy: A century of promise, a decade of progress. Nat. Clin. Pract. Oncol. 2007, 4, 101-117. [CrossRef]

119. Campadelli-Fiume, G.; De Giovanni, C.; Gatta, V.; Nanni, P.; Lollini, P.-L.; Menotti, L. Rethinking herpes simplex virus: The way to oncolytic agents. Rev. Med. Virol. 2011, 21, 213-226. [CrossRef]

120. Harrington, K.J.; Freeman, D.J.; Kelly, B.; Harper, J.; Soria, J.-C. Optimizing oncolytic virotherapy in cancer treatment. Nat. Rev. Drug Discov. 2019, 18, 689-706. [CrossRef]

121. Twumasi-Boateng, K.; Pettigrew, J.L.; Kwok, Y.Y.E.; Bell, J.C.; Nelson, B.H. Oncolytic viruses as engineering platforms for combination immunotherapy. Nat. Rev. Cancer 2018, 18, 419-432. [CrossRef]

122. Senior, M. Checkpoint inhibitors go viral. Nat. Biotechnol. 2019, 37, 12-17. [CrossRef] [PubMed]

123. Yong, C.S.M.; Dardalhon, V.; Devaud, C.; Taylor, N.; Darcy, P.K.; Kershaw, M.H. CAR T-cell therapy of solid tumors. Immunol. Cell Biol. 2017, 95, 356-363. [CrossRef] [PubMed]

124. Grupp, S.A.; Kalos, M.; Barrett, D.; Aplenc, R.; Porter, D.L.; Rheingold, S.R.; Teachey, D.T.; Chew, A.; Hauck, B.; Wright, J.F.; et al. Chimeric Antigen Receptor-Modified T Cells for Acute Lymphoid Leukemia. N. Engl. J. Med. 2013, 368, 1509-1518. [CrossRef] [PubMed]

125. Zhang, C.; Wang, Z.; Yang, Z.; Wang, M.; Li, S.; Li, Y.; Zhang, R.; Xiong, Z.; Wei, Z.; Shen, J.; et al. Phase I Escalating-Dose Trial of CAR-T Therapy Targeting CEA + Metastatic Colorectal Cancers. Mol. Ther. 2017, 25, 1248-1258. [CrossRef]

126. Hege, K.M.; Bergsland, E.K.; Fisher, G.A.; Nemunaitis, J.J.; Warren, R.S.; McArthur, J.G.; Lin, A.A.; Schlom, J.; June, C.H.; Sherwin, S.A. Safety, tumor trafficking and immunogenicity of chimeric antigen receptor (CAR)-T cells specific for TAG-72 in colorectal cancer. J. Immunother. Cancer 2017, 5, 22. [CrossRef]

127. Wang, Y.; Chen, M.; Wu, Z.; Tong, C.; Dai, H.; Guo, Y.; Liu, Y.; Huang, J.; Lv, H.; Luo, C.; et al. CD133-directed CAR T cells for advanced metastasis malignancies: A phase I trial. OncoImmunology 2018, 7, e1440169. [CrossRef]

128. Shenzhen Second People's Hospital. EGFR-IL12-CART Cells for Patients with Metastatic Colorectal Cancer. Available online: https:/clinicaltrials.gov/ct2/show/NCT03542799 (accessed on 20 September 2020).

129. Celyad Oncology SA. alloSHRINK-Standard cHemotherapy Regimen and Immunotherapy with Allogeneic NKG2D-Based CYAD-101 Chimeric Antigen Receptor T-Cells. Available online: https:/clinicaltrials.gov/ct2/ show/NCT03692429 (accessed on 20 September 2020). 
130. Chongqing Precision Biotech Co., Ltd. Clinical Study of CEA-Targeted CAR-T Therapy in Patients with Relapsed and Refractory CEA+ Cancer. Available online: https://clinicaltrials.gov/ct2/show/NCT04348643 (accessed on 20 September 2020).

131. Shenzhen Second People's Hospital. EGFR CART Cells for Patients with Metastatic Colorectal Cancer. Available online: https://linicaltrials.gov/ct2/show/NCT03152435 (accessed on 20 September 2020).

132. Shenzhen BinDeBio Ltd. Autologous CAR-T/TCR-T Cell Immunotherapy for Malignancies. Available online: https://clinicaltrials.gov/ct2/show/NCT03638206 (accessed on 20 September 2020).

133. Li, J.; Li, W.; Huang, K.; Zhang, Y.; Kupfer, G.; Zhao, Q. Chimeric antigen receptor T cell (CAR-T) immunotherapy for solid tumors: Lessons learned and strategies for moving forward. J. Hematol. Oncol. 2018, 11, 1-18. [CrossRef]

134. Titov, A.; Valiullina, A.; Zmievskaya, E.; Zaykova, E.; Petukhov, A.; Miftakhova, R.; Bulatov, E.; Rizvanov, A. Advancing CAR T-Cell Therapy for Solid Tumors: Lessons Learned from Lymphoma Treatment. Cancers 2020, 12, 125. [CrossRef]

135. Hartmann, J.; Schüßler-Lenz, M.; Bondanza, A.; Buchholz, C.J. Clinical development of CAR T cells-challenges and opportunities in translating innovative treatment concepts. EMBO Mol. Med. 2017, 9, 1183-1197. [CrossRef]

136. Tanoue, K.; Shaw, A.R.; Watanabe, N.; Porter, C.; Rana, B.; Gottschalk, S.; Brenner, M.; Suzuki, M. Armed Oncolytic Adenovirus-Expressing PD-L1 Mini-Body Enhances Antitumor Effects of Chimeric Antigen Receptor T Cells in Solid Tumors. Cancer Res. 2017, 77, 2040-2051. [CrossRef]

137. Hegde, U.P.; Mukherji, B. Current status of chimeric antigen receptor engineered T cell-based and immune checkpoint blockade-based cancer immunotherapies. Cancer Immunol. Immunother. 2017, 66, 1113-1121. [CrossRef] [PubMed]

138. John, L.B.; Devaud, C.; Duong, C.P.; Yong, C.S.; Beavis, P.A.; Haynes, N.M.; Chow, M.T.; Smyth, M.J.; Kershaw, M.H.; Darcy, P.K. Anti-PD-1 Antibody Therapy Potently Enhances the Eradication of Established Tumors By Gene-Modified T Cells. Clin. Cancer Res. 2013, 19, 5636-5646. [CrossRef] [PubMed]

139. Van De Wetering, M.; Francies, H.E.; Francis, J.M.; Bounova, G.; Iorio, F.; Pronk, A.; Van Houdt, W.; Van Gorp, J.; Taylor-Weiner, A.; Kester, L.; et al. Prospective derivation of a living organoid biobank of colorectal cancer patients. Cell 2015, 161, 933-945. [CrossRef] [PubMed]

140. Xia, X.; Li, F.; He, J.; Aji, R.; Gao, D. Organoid technology in cancer precision medicine. Cancer Lett. 2019, 457, 20-27. [CrossRef]

141. Ms, S.D.F.; Moaven, O.; Votanopoulos, K.I. ASO Author Reflections: Patient-Derived Tumor Organoids-A Platform for a Precision Approach for Peritoneal Malignancies. Ann. Surg. Oncol. 2020, 27, 4961-4962. [CrossRef]

142. Vlachogiannis, G.; Hedayat, S.; Vatsiou, A.; Jamin, Y.; Fernández-Mateos, J.; Khan, K.; Lampis, A.; Eason, K.; Huntingford, I.; Burke, R.; et al. Patient-derived organoids model treatment response of metastatic gastrointestinal cancers. Science 2018, 359, 920-926. [CrossRef]

143. Kim, S.Y.; Kim, T.W. Current challenges in the implementation of precision oncology for the management of metastatic colorectal cancer. ESMO Open 2020, 5, e000634. [CrossRef]

144. Votanopoulos, K.I.; Mazzocchi, A.; Sivakumar, H.; Forsythe, S.; Aleman, J.; Levine, E.A.; Skardal, A. Appendiceal Cancer Patient-Specific Tumor Organoid Model for Predicting Chemotherapy Efficacy Prior to Initiation of Treatment: A Feasibility Study. Ann. Surg. Oncol. 2018, 26, 139-147. [CrossRef]

145. Ms, S.D.F.; Ms, S.S.; Moaven, O.; Ms, H.S.; Shen, P.; Levine, E.A.; Soker, S.; Skardal, A.; Votanopoulos, K.I. Personalized Identification of Optimal HIPEC Perfusion Protocol in Patient-Derived Tumor Organoid Platform. Ann. Surg. Oncol. 2020, 27, 4950-4960. [CrossRef]

146. Hidalgo, M.; Amant, F.; Biankin, A.V.; Budinská, E.; Byrne, A.T.; Caldas, C.; Clarke, R.B.; De Jong, S.; Jonkers, J.; Mælandsmo, G.M.; et al. Patient-Derived Xenograft Models: An Emerging Platform for Translational Cancer Research. Cancer Discov. 2014, 4, 998-1013. [CrossRef]

147. Mazzocchi, A.R.; Rajan, S.A.P.; Votanopoulos, K.I.; Hall, A.R.; Skardal, A. In vitro patient-derived 3D mesothelioma tumor organoids facilitate patient-centric therapeutic screening. Sci. Rep. 2018, 8, 1-12. [CrossRef] [PubMed] 
148. Xie, J.; Lin, Y. Patient-derived xenograft models for personalized medicine in colorectal cancer. Clin. Exp. Med. 2020, 20, 167-172. [CrossRef] [PubMed]

149. Forsythe, S.; Mehta, N.; Devarasetty, M.; Sivakumar, H.; Gmeiner, W.; Soker, S.; Votanopoulos, K.; Skardal, A. Development of a Colorectal Cancer 3D Micro-tumor Construct Platform From Cell Lines and Patient Tumor Biospecimens for Standard-of-Care and Experimental Drug Screening. Ann. Biomed. Eng. 2019, 48, 940-952. [CrossRef]

Publisher's Note: MDPI stays neutral with regard to jurisdictional claims in published maps and institutional affiliations.

(C) 2020 by the authors. Licensee MDPI, Basel, Switzerland. This article is an open access article distributed under the terms and conditions of the Creative Commons Attribution (CC BY) license (http://creativecommons.org/licenses/by/4.0/). 